\title{
Material and energy flow analysis of the Malawian tea industry
}

\author{
J.L. Taulo ${ }^{1, \text { a }}$, A.B. Sebitosi ${ }^{1, \mathbf{b}}$ \\ ${ }^{1}$ Department of Mechanical \& Mechatronic Engineering, Stellenbosch University, P/Bag X1, Matieland 7602, South Africa \\ a.johntaulo@sun.ac.za, ${ }^{b}$ sebitosi@sun.ac.za
}

\begin{abstract}
This paper briefly reviews the material and energy flows of the Malawian tea industry, in order to identify opportunities and reduce its environmental impacts. The review also details the concept and methodology as well as studies on applications of material and energy flow analysis. Environmental impacts are calculated with a life cycle assessment approach, using CML methodology. Results indicate that green leaf consumption in the studied factories ranged from 4.19 to $6.33 \mathrm{~kg}$ green leaf $/ \mathrm{kg}$ made tea (MT), with an average of $4.96 \mathrm{~kg}$ per $\mathrm{kg}$ of made tea compared to 4.5 and $4.66 \mathrm{~kg}$ green leaf for tea factories in Kenya and Sri Lanka, respectively. Average wood consumption in Malawian tea factories is $3.35 \mathrm{~kg} / \mathrm{kg}$ made tea and specific water consumption ranged from 1.92 to $8.32 \mathrm{~kg} / \mathrm{kg} \mathrm{MT}$. In addition, the average value of greenhouse gas (GHG) emissions for eight factories is $4.32 \mathrm{~kg}$ of $\mathrm{CO}_{2}$-eq $/ \mathrm{kg}$ MT as compared to 2.27 and $2.7 \mathrm{~kg} \mathrm{CO}$-eq/ $/ \mathrm{kg}$ in similar factories in Kenya and Sri Lanka, respectively. The major sources emitting GHG are from boiler fuel combustion and stand-by diesel power generation system. The study indicates that global warming has the highest environmental impact (88\%), followed by acidification $(6 \%)$ and eutrophication $(2 \%)$, whereas human toxicity is lowest $(<1 \%)$. The findings demonstrate how MEFA provides early recognition of environmental problems and how it can be used to establish priorities for improving operations in the existing factories.
\end{abstract}

Keywords: Tea industry, Material flow analysis, Malawi, Environmental impact, Greenhouse gases

\subsection{Introduction}

Tea (Camellia sinensis) is an important agricultural and export cash crop in Malawi. Tea industry comprises 1.5 percent of Malawi's Gross Domestic Product (GDP), contributes 11 percent of the national employment, and accounts for 8 percent of foreign exchange earnings [1]. In addition, the industry generates about 40,000 to 60,000 direct jobs and 1.5 million indirect with annual turnover of sixteen billion Malawi Kwacha (US\$86 million), making it the third largest export earner, after tobacco and sugar, respectively. Total land area under tea cultivation in the country is about 19,000 hectares and the annual tea production is approximately 46,500 tonnes, which accounts for 1.3 percent of total world production [2]. Malawi is now ranked the thirteenth largest tea growing country in the world and the third largest producer in Africa after Kenya and Uganda, respectively [3]. At present there are in total 21 tea factories in the country, most of which are located in the southern part of Malawi[4].

However, despite its importance to the economy, tea cultivation and processing significantly contributes to negative environmental impacts. Major impacts of the tea processing industry on the environment are related to habitat conversion, energy and agrochemical use, and wastewater generation [5]. More recent studies have shown that there is significant biodiversity loss due to conversion of forests into tea farms [6]. In addition to habitat conversion, logging of firewood from local forests needed for drying tea has led to deforestation. Since not all tea factories have sustainable plantations from which they would harvest wood fuel, natural forests remain the major source.

Tea factories also emit gaseous, liquid as well as particulate pollutants. The main sources of pollution are waste water from factory processes and exhaust fumes from boilers, standby generator sets and factory trucks that carry green leaf to the factory. Pesticides and chemical fertilizers are also sources of pollution. The environmental impacts of these pollutants vary. Waste water discharged from tea processing factories cause high levels of colour, chemical oxygen demand (COD), and biochemical 
oxygen demand (BOD) [7], [8]. Pesticides and chemical fertilizers affect water quality and aquatic ecosystems. Exhaust fumes release carbon dioxide and nitrous oxides which are greenhouse gases that cause global warming, sulphur dioxide which is responsible for acid rain and particulate matter which affect human health. Tea factories are also energy intensive.

Material and energy flow analysis (MEFA) has been widely recognized as one important and necessary step for reducing the impacts of human activities on the environment [9], [10], [11]. MEFA utilises process material and energy input-output data to characterise the use and emission of materials within and between processes. All flows and indicators are measured in mass units, giving a physical quantification of the system's material requirements. Furthermore, it can be used to reduce the consumption of energy, raw material, water and discharge of effluents by pursuing systematically internal flows of energy and mass in production processes. MEFA is increasingly applied in the fields of industrial ecology, environmental management and protection, resource management, and waste management. It is also used as a basis for life cycle assessment, eco-balance, environmental impacts strategies [12]. Recently the methodology has been applied to optimise material flows and waste streams in production processes in different countries [13],[14],[15],[16]. However, to the best of the author's knowledge, there is surprisingly lack of published data and research on material and energy analysis of the tea industry.

The objective of this paper is to review the information available, introduce and discuss the applicability of MEFA approach to the Malawian tea industry. The study is the first step in developing MEFA methods to analyse and monitor the material and energy flows of the tea industry. The essence of this study is to identify improvement opportunities in the tea manufacturing process and reduce their environmental impacts while maximising economic, social and environmental benefits.

\subsection{Material and energy flow analysis}

\section{$2.1 \quad$ Conceptual framework}

Material and energy flow analysis (MEFA) is a systematic assessment of the flows and stocks of materials (including energy) within a system defined by space and time [9]. It is an analytical tool that examines the material stocks and flows coming into and out of a given system, and the resulting outputs from the system [10], [9], [17]. MEFA constitutes an important approach to track the use of materials and energy by socio-economy systems from extraction to manufacturing, to final uses and disposal of emissions and wastes. The material flow approach can be traced back to the second half of the nineteenth century [18], but current approaches rely on methods developed in the late 1960s and early 1970s [19]. The aim is to trace the physical flow of materials, products and wastes associated with particular economic activities. MEFA uses the principle of mass balancing to study how material and energy flows interact with the economy and the environment [20]. The principle of mass balancing is based on the first law of thermodynamics, which states that matter (mass, energy) is neither created nor destroyed by any physical transformation process. Material inputs into a system must therefore always equal material outputs plus net accumulation of materials in the system (material balance principle). Material that flows into the system builds up and maintains the system's material compartments (stocks). Conversely, all materials required to maintain a system compartment or stock must be considered part of the system's relevant material flows.

Material flows can be analysed on several spatial scales and with different instruments depending on the issue of concern and on the objects of interest of the study. The analysis can be applied to the complete collection of resources and products flowing through a system to single chemical elements. MEFA can be applied to various scales and types of systems, e.g. companies, economic sectors, households, national economies, the world economy, or villages, cities, river basins, nation states and world regions [21]. MEFA may include different types of materials. The objects for analysis may range 
from specific elements or substances, for example copper [22],[23] or chlorine [24], [25], to all material inputs, including water and air. According to different subjects and various methods, MEFA covers approaches such as Substance Flow Analysis (SFA), product flow accounts, material balancing, and overall material flow accounts [26].

The principle concept underlying the MFA approach is simple model of the interrelationship between the economy and the environment, in which the economy is an embedded subsystem of the environment and - similar to living beings - dependent on the constant throughput of materials and energy [10,27]. Raw materials, water and air are extracted from the natural systems as inputs, transformed into products and finally re-transferred to the natural systems as outputs (waste and emissions). To highlight the similarity to natural metabolic processes, the terms "industrial" [28] or "societal" [18] metabolism have been introduced.

\subsection{MFA definitions}

To understand the construction and quantifications of the MEFA approach it is important to recognise the definitions applied. The review uses the definitions from the Practical handbook of Material Flow Analysis by Brunner and Rechberger [9], which are declared in Table 1.

\section{Table 1}

Terminology used in MEFA [9]

\begin{tabular}{|c|c|}
\hline Term & Definition \\
\hline Material & Generic term for substances and/or goods flowing through the system \\
\hline Substance & A chemical element (atom) or compound (molecule) \\
\hline Good & $\begin{array}{l}\text { A material with a positive or negative market value, for example food and } \\
\text { waste water }\end{array}$ \\
\hline Process & $\begin{array}{l}\text { The transformation, transport or storage of material. A process can be natural } \\
\text { or man-made }\end{array}$ \\
\hline Stock & $\begin{array}{l}\text { The storage of material in a process. It is illustrated as a little box within the } \\
\text { process box }\end{array}$ \\
\hline Flow & $\begin{array}{l}\text { An inflow (input) is entering a process and an outflow (output) is exiting a } \\
\text { process. Import and export are the flows in and out from the system. The flow } \\
\text { is defined as "mass per time" and can for example be measured in } g \text { year }^{-1}\end{array}$ \\
\hline Flux & $\begin{array}{l}\text { The flux is defined as "mass per time and cross section" and can be measured } \\
\text { in } \mathrm{kg} \mathrm{sec}^{-1} \mathrm{~m}^{-2} \text { or } \mathrm{g} \mathrm{cap}^{-1} \mathrm{year}^{-1} \text {. }\end{array}$ \\
\hline Transfer coefficient & $\begin{array}{l}\text { The division of a substance in a process. The percentage of a process's input } \\
\text { that is directed to each output }\end{array}$ \\
\hline Parameter & $\begin{array}{l}\text { The data used for describing the process, i.e. flows, concentration, area and } \\
\text { mass }\end{array}$ \\
\hline System boundary & The geographic or organizational border of the defined system \\
\hline
\end{tabular}

\subsection{Applications of Material and Energy Flow Analysis}

Material and energy flow analysis has become a widely used policy decision support tool in many fields, including process control, resource management, waste treatment, environmental management, product design, and life cycle assessment [9], [29]. Table 2 gives an overview of the studies examined on the application of material flow analysis. 
Table 2

Application of Material and Energy Flow Analysis in the reviewed literature

\begin{tabular}{|c|c|c|c|}
\hline Study criteria & Goods & Substances & References \\
\hline \multirow[t]{2}{*}{ Substance level } & & Metals & $\begin{array}{l}\text { [30], [31], [32], [33], [34], } \\
\text { [35], [36], [37], [38], [12], } \\
{[24],[25],[22],[23]}\end{array}$ \\
\hline & & Periodic table elements & [39] \\
\hline \multirow{4}{*}{$\begin{array}{l}\text { Goods and } \\
\text { substance level }\end{array}$} & Construction materials & Mixture & [40] \\
\hline & Land trade & & [41] \\
\hline & & Metals & [42], [43], [44], [45] \\
\hline & General & Problematic substances & $\begin{array}{l}{[46],[47],[48],[49],[50],} \\
{[15],[51],[52]}\end{array}$ \\
\hline \multirow[t]{6}{*}{ Goods } & Wood & & {$[17],[53],[54],[55]$} \\
\hline & Food products & & [56], [57], [58], [59], [60] \\
\hline & Waste streams & & $\begin{array}{l}\text { [61], [62], [63], [64], [65], } \\
{[13],[38],[14],[15]}\end{array}$ \\
\hline & Plastics & & {$[66]$} \\
\hline & Tailoring & & [67] \\
\hline & Internet, ceramics & & {$[68],[69]$} \\
\hline
\end{tabular}

\subsection{Materials and methods}

\subsection{MEFA methodology}

The main tool used for this study is the Material and Energy Flow Analysis. It consists of determining and quantifying all flows that are inputs and outputs in a system with the goal of assessing the interchange of resources between the system and the environment. Detailed methodological steps of MEFA are described in [10], [70], [71]. Material and energy flow analysis contains the following main steps [9]: (1) definition of the system under study, (2) system description, (3) data acquisition, (4) modeling and scenario building, and (5) results and discussion.

\section{(1) Definition of the system under study}

The first step of MFA is the identification of the industrial plant. It involves the qualitative analysis of the selected process: identification of its limits, definition and description of its stages, and analysis of inputs and outputs and internal flows. This analysis must be based on technical visits to the plant and on bibliographic review.

\section{(2) System description.}

The MEFA system under consideration is defined with regard to space (e.g. a city, province, country, or industry), function (e.g. processes), time horizon (e.g. a year) and materials (e.g. the studied substance). If necessary, the system can be divided into subsystems. 


\section{(3) Data acquisition}

The flows and stocks can be determined by direct measurements, market research, expert judgment, best estimates, interviews, databases of environmental protection agencies, scientific papers, technical handbooks and so on.

\section{(4) Modeling and scenario building.}

Energy and material balances are performed on those processes where no data is available. The results obtained can be integrated into the model. Computer software of a different degree of complexity are available to support this analysis. The structure of the model for the process considered must be set up carefully to guarantee the quality of the results from the simulation

\section{(5) Results and discussion.}

The results obtained can be compared with environmental standards and/or sustainable indicators or even other assessment approaches. All of them contribute to design control measures, to identify new problems and best of all, new solutions.

\subsection{Material and energy analysis: applications to tea processing}

\subsubsection{System definition and boundary}

This study focussed on the Malawian tea industry, and aims to: (a) analyse the material streams, processes and flows within tea production system; (b) determine and quantify the material and energy consumption for the industry using the MEFA method; and (c) evaluate the environmental inputs and outputs associated with tea manufacture at the factory. The study has a gate-to-gate system boundary and starts at the weighbridge where green leaf from tea fields is received and ends at the production of dried tea at the factory gate. In addition, it includes the energy unit producing electricity (diesel generator), process steam and heat (boilers) as shown in Figure 1. Upstream activities ${ }^{1}$ and downstream activities $^{2}$ (e.g. distribution and use stage) have not been included in the system. The function unit for this study is $1 \mathrm{~kg}$ of made tea in Malawi. Fig. 1 also shows the processes and stages included in the system boundary.

\subsubsection{System description}

Tea processing consists of the following main steps: withering, rolling, oxidation, drying, and sorting and grading. Freshly plucked tea leaves are brought to the factory where they are first withered. Withering is an important processing step applied to reduce the moisture content of the leaf from 75$83 \%$ (wet basis) to $68-72 \%$ (wet basis) and to prepare the leaf chemically and physically for the subsequent stages of manufacture [72]. In addition, many physical and biochemical changes take place during withering process and results in: an increase in the level of amino acids [73], caffeine content [74], sugars [75], polyphenol oxidase activity [76]; changes in chlorophyll content [77]; formation of precursors of volatile flavour compounds [78]; and an increase in cell membrane permeability [79]. Withering duration ranges from 6 to 20 hours and is a function of relative humidity of the surrounding air, temperature, and the flow velocity of the withering air [80].

\footnotetext{
${ }^{1}$ Tea cultivation, production, and transportation to factory

${ }^{2}$ Distribution and usage stage
} 
Withered leaf is cut or macerated using rollers, Lawrie Tea Processor (LTP) or Cut-Tear-Curl (CTC) machines. Rolling bruises the leaves, disrupting the leaf cell structure and brings tea polyphenols and polyphenol oxidase and oxygen in contact, which promotes the oxidation of tea polyphenols and formation of red pigments (thearubigins) and yellow pigments (theaflavins). The macerated leaf or dhool is cooled to temperatures below $35^{\circ} \mathrm{C}$ to preserve quality. Tea leaves are then subjected to the process of fermentation/oxidation by moving conveyors under controlled temperature, humidity and air flow conditions. Cool air is circulated through the crushed leaves to moderate the reaction, as the onset of fermentation is accompanied by a rise in temperature from the exothermic fermentation process.

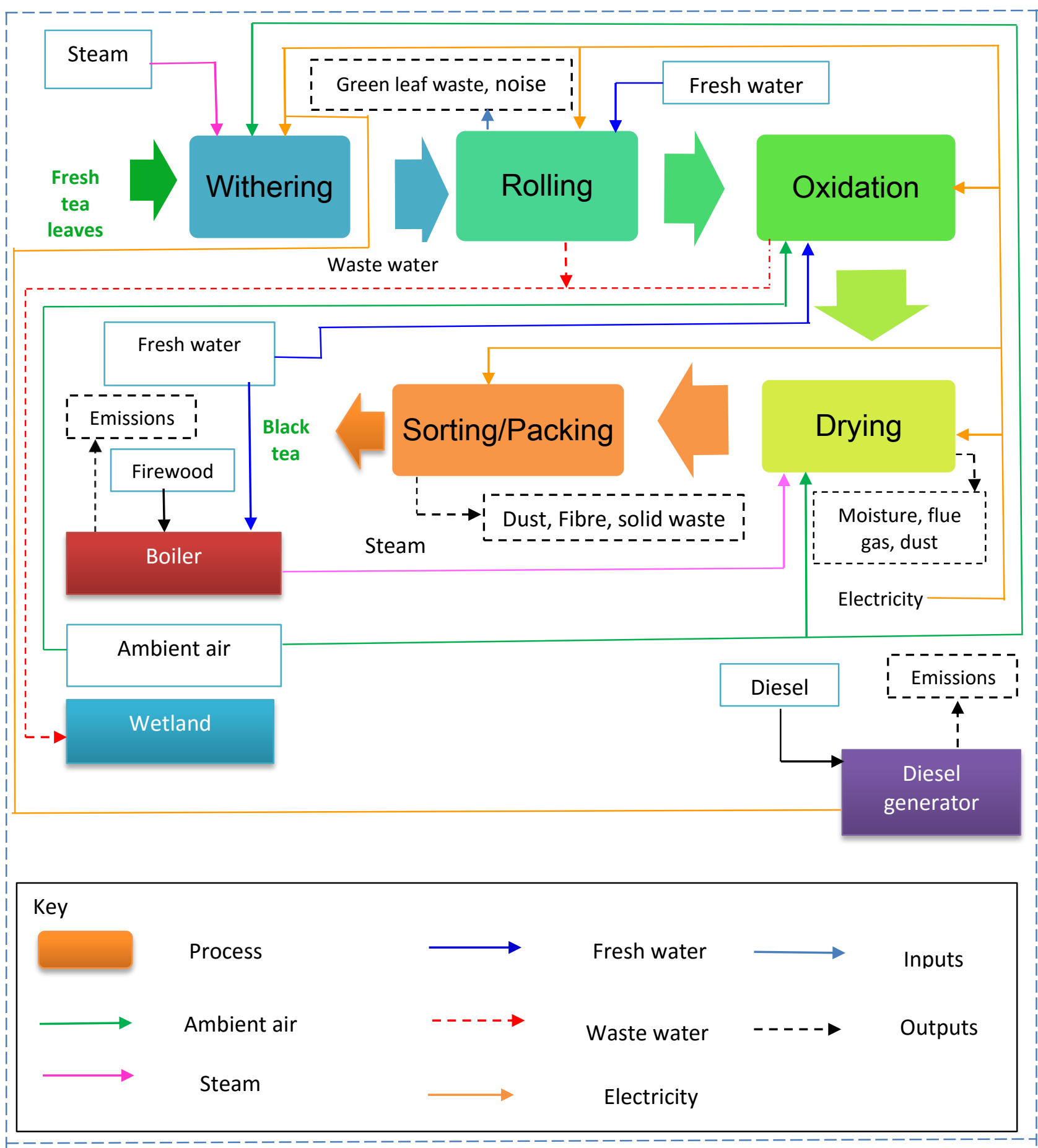

Figure 1: Process flow diagram for tea factory

Humidifiers mounted within the belt fermentation assembly are also used to improve the ability to absorb clean air, and whenever needed. Fermentation/oxidation in tea leaves results in the production of 
different chemical compounds, such as "theaflavins (TF)" and "thearubigins (TR)"which respectively contribute to taste, strength and colour of tea. Fermentation/oxidation time depends on the ambient temperature, degree of maceration, degree of wither, and the type of tea to be produced. Typically it ranges from 45 to 60 minutes and 60 to 105 minutes for fast and slow fermenting cultivars, respectively. Temperatures between 20 and $30^{\circ} \mathrm{C}$, with high humidity (95\%) and ample exposure of the macerated leaf to the air are found to be satisfactory.

The last step of black tea manufacture involves drying with a blast of hot air. Fermented tea leaves are fired to arrest further fermentation, deactivate the enzymes and remove almost all residual moisture in the leaf. The leaf is passed through fluidized bed dryers, which have circuit trays with perforations, on which are conveyed the fermented leaf. The drying process takes about $20-25 \mathrm{~min}$ and the inlet air temperature is about $120-140^{\circ} \mathrm{C}$ and is finished off at a temperature of $80-90^{\circ} \mathrm{C}$. The moisture level of the tea when drying is completed is approximately 2-3\%. According to Keegel [81], drying is influenced by the inlet temperature, thickness of spread of the dhool, air flow rate, period of drying, and moisture content of the dhool. Dried tea is sorted into different grades by passing it over a series of vibratory screens of different mesh sizes. Stalk is removed by the use of electrostatic separators. The graded tea is finally weighed and packaged into sacks or wooden chests, and subsequently sold at the local and regional auctions. Process steps and the generated wastes from these steps are also given in Fig.1.

\subsubsection{Data acquisition}

The empirical data of this study was collected from eight of the twenty one tea factories in Malawi. Purposive and convenience sampling techniques [82] were applied to select a sample of factories for this study. The factories have different processing capacities of green leaves ranging from 90 to 240 tons per day. They accounted for approximately 38 percent of total production capacity in the country. Data were collected from these factories through plant reports, direct on-site measurement and literature review. The inventory data which consisted of raw materials, energy consumption, wastes and emissions were collected for a period of seven years from each factory. Data analysis included material and energy inputs and outputs at each stage of tea production. Finally, mass and energy balances for a complete factory and the unit processes were established.

\subsubsection{Mathematical modelling}

\subsubsection{Governing equations}

Mass balances can be expressed in the rate form as given by the following general equation:

$\sum \dot{m}_{\text {in }}=\sum \dot{m}_{\text {out }}$

where $\dot{m}$ is the mass flow rate, and the subscripts in stands for inlet and out for outlet. Material balances for each step of tea production shown in Fig.1 can be described by Eq. (2):

$\sum_{j=1}^{p} \dot{m}_{i n, j}=\sum_{k=1}^{n} \dot{m}_{o u t, k}$

where $j$ represents the type of material inputs with a total of $p$ inputs, and $k$ represents the type of material outputs with a total of $n$ outputs. 
Energy balance for the considered unit process is given by the following equation:

$\sum \dot{E}_{\text {in }}=\sum \dot{E}_{\text {out }}$

where $\dot{E}_{\text {in }}$ denotes energy rate $(\mathrm{kJ})$

\section{(1) Withering}

Dry air mass balance: $\quad \dot{m}_{a 1}=\dot{m}_{a 2}=\dot{m}_{a}$

Water mass balance: $\quad \omega_{1} \dot{m}_{a}=\dot{m}_{a 2} \omega_{2}+\dot{m}_{w} \rightarrow \dot{m}_{w}=\dot{m}_{a}\left(\omega_{2}-\omega_{1}\right)$

Energy balance: $\quad \sum \dot{m}_{\text {in }} h_{\text {in }}=\dot{Q}_{\text {out }}+\sum \dot{m}_{\text {out }} h_{\text {out }} \rightarrow \dot{Q}_{\text {out }}=\dot{m}_{a}\left(h_{1}-h_{2}\right)-\dot{m}_{w} h_{w}$

where $\dot{m}_{a 1}$ and $\dot{m}_{a 2}$ is mass flow rate of air at the inlet and outlet, respectively; $\omega_{1}$ and $\omega_{2}$ represent the humidity ratio of air at the inlet and outlet, respectively; $\dot{m}_{w}$ is the mass flow rate of water; $h_{1}$ and $h_{2}$ denote the specific enthalpy at the inlet and outlet, respectively; and $\dot{Q}_{\text {out }}$ is the rate of heat transfer.

\section{Rolling/maceration}

Dhool balance: $\quad\left(\dot{m}_{d h}\right)_{1}=\left(\dot{m}_{d h}\right)_{2}=\dot{m}_{d h}$

where $\left(\dot{m}_{d h}\right)_{1}$ and $\left(\dot{m}_{d h}\right)_{2}$ is the mass flowrate of dhool.

\section{Continuous Oxidation/Fermentation}

Equations governing mass and energy balance in the continuous fermentation or oxidation process are given as [83]:

Dry air mass balance: $\quad \dot{m}_{a 1}=\dot{m}_{a 2}=\dot{m}_{a}$

Water mass balance: $\quad \omega_{1} \dot{m}_{a}=\dot{m}_{a 2} \omega_{2}+\dot{m}_{w} \rightarrow \dot{m}_{w}=\dot{m}_{a}\left(\omega_{2}-\omega_{1}\right)$

Energy balance: $\quad \sum \dot{m}_{\text {in }} h_{\text {in }}=\dot{Q}_{\text {out }}+\sum \dot{m}_{\text {out }} h_{\text {out }} \rightarrow \dot{Q}_{\text {out }}=\dot{m}_{a}\left(h_{1}-h_{2}\right)-\dot{m}_{w} h_{w}$

\section{(4) Drying}

Mass balance equations for the dryer shown in Fig 2 can be written considering three components such as fermented or fresh tea leaves, air and the water which exists in the drying air and tea. Mass balance for air, tea and water are given by the equations proposed by Dincer and Sahin [84]:

Air: $\quad\left(\dot{m}_{a}\right)_{1}=\left(\dot{m}_{a}\right)_{3}=\dot{m}_{a}$

Tea: $\quad\left(\dot{m}_{p}\right)_{2}=\left(\dot{m}_{p}\right)_{4}=\dot{m}_{p}$

Water: $\quad \omega_{1} \dot{m}_{a}+\left(\dot{m}_{w}\right)_{2}=\omega_{3} \dot{m}_{a}+\left(\dot{m}_{w}\right)_{4}$ 
where $\dot{m}_{a}$ is mass flow rate of air, $\dot{m}_{p}$ mass flow rate of tea leaves, $\omega$ is the humidity ratio of air, and $\dot{m}_{w}$ mass flow rate of water.

Energy balance: $\quad \sum \dot{m}_{\text {in }} h_{\text {in }}=\sum \dot{m}_{\text {out }} h_{\text {out }}$

Consequently, the overall energy balance of the dryer can be written as follows [84]:

$\dot{m}_{a} h_{1}+\dot{m}_{p}\left(h_{p}\right)_{2}+\left(\dot{m}_{w}\right)_{2}\left(h_{w}\right)_{2}=\dot{m}_{a} h_{3}+\dot{m}_{p}\left(h_{p}\right)_{4}+\left(\dot{m}_{w}\right)_{4}\left(h_{w}\right)_{4}+\dot{Q}_{l}$

where $h_{1}=\left(h_{a}\right)_{1}+\omega_{1}\left(h_{v}\right)_{1} \simeq\left(h_{a}\right)_{1}+\omega_{1}\left(h_{g}\right)_{2}$

$h_{3}=\left(h_{a}\right)_{3}+\omega_{3}\left(h_{g}\right)_{3}$

where $h$ is specific enthalpy; $h_{p}$ specific enthalpy of tea; $h_{g}$ specific enthalpy at saturated vapour state; $h_{w}$ specific enthalpy of water; $h_{a}$ specific enthalpy of air, $\dot{m}$ mass flow rate; $\dot{Q}_{l}$ rate of heat transfer loss; and $\omega$ humidity ratio of air.

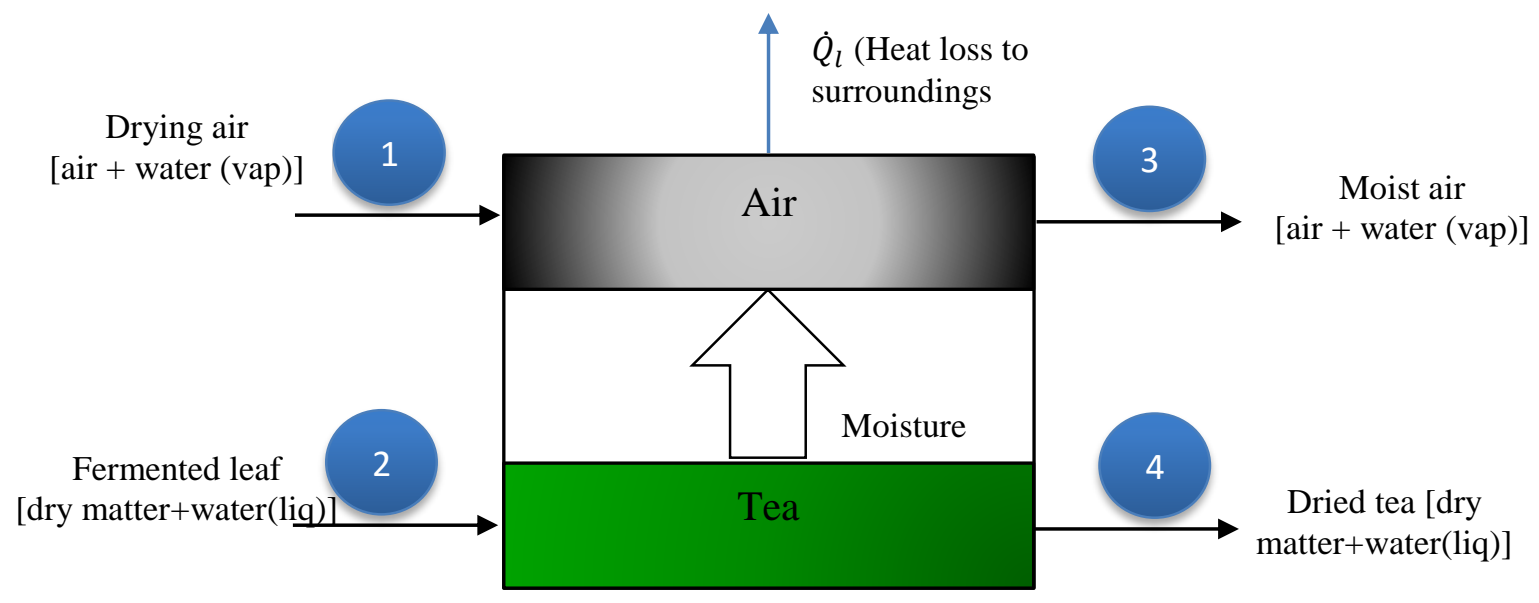

Figure 2: Schematic of drying process with inputs and outputs [28]

Eq. (12) can be used to calculate the heat loss rate from the dryer chamber:

$\dot{Q}_{l}=\dot{m}_{a} q_{l}$

where $\dot{m}_{a}, q_{l}$ represent mass flow rate of air and heat transfer related loss, respectively.

\section{Sorting and grading}

Dried tea: $\quad\left(\dot{m}_{d t}\right)_{1}=\left(\dot{m}_{d t}\right)_{2}=\dot{m}_{d t}$

where $\left(\dot{m}_{d t}\right)_{1}$ and $\left(\dot{m}_{d t}\right)_{2}$ is the mass flowrate of dried tea. 


\subsubsection{Parameters and thermal properties}

Enthalpy (heat content) of drying air and the specific heat on inlet and outlet air is determined via Eq.(14) and Eq.(15), respectively.

$h_{a}=C_{s}\left(T_{a}-T_{0}\right)+\omega h_{L}$

$C_{s}=1.005+1.88 \omega$

where $C_{s}$ is the humid heat ( $\mathrm{kJ} / \mathrm{dry}$ air); $T_{a}$ is air temperature $\left({ }^{\circ} \mathrm{C}\right), T_{0}$ is reference temperature $\left({ }^{\circ} \mathrm{C}\right), \omega$ is the absolute humidity ( $\mathrm{kg}$ water $/ \mathrm{kg}$ dry air) of inlet drying air, $h_{L}$ is the latent heat of vaporization of water $(\mathrm{kJ} / \mathrm{kg}$ water $)$.

Bhuyan [85] proposes the following equation for calculating the mass of air needed for the drying:

$m_{a}=\frac{m_{p}\left[C_{p p}\left(T_{p 1}-T_{p 2}\right)+C_{P w}\left(W_{1} T_{p 1}-W_{2} T_{p 2}\right)\right]}{C_{s 1} T_{a 2}-C_{s 2} T_{a 1}+h_{L}\left(\omega_{2}-\omega_{1}\right)}$

where $C_{s 1}=1.005+1.88 \omega_{1} ; \quad C_{s 2}=1.005+1.88 \omega_{2} ; T_{p 1}$ and $T_{p 2}$ are inlet and out temperatures of tea, $W_{1}$ and $W_{2}$ are moisture content of tea at inlet and exhaust; $T_{a 1}$ and $T_{a 2}$ are the inlet and exhaust temperatures of drying air, respectively, $\omega$ is the absolute humidity, and $m_{p}$ is the feed rate of tea.

The heat content of tea leaves is evaluated from the following equation:

$h_{p}=W C_{p w} C_{p p}\left(T_{p}-T_{0}\right)$

where $W$ is the moisture content of the product ( $\mathrm{kg}$ water $/ \mathrm{kg}$ of dry solid product), $C_{p w}$ is the specific heat of water $(\mathrm{kJ} / \mathrm{kg} . \mathrm{K}), C_{p p}$ is the specific heat of product $(\mathrm{kJ} / \mathrm{kg} . \mathrm{K})$, and $T_{p}, T_{0}$ are product and reference temperatures, respectively.

Mass of dried material and the amount of moisture removed from tea leaves are quantified according to Eqs. (18) and (19), respectively.

$m_{d m}=m_{w m} \cdot \frac{\left(100-X_{w m}\right)}{\left(100-D M_{c}\right)}$

$m_{e v}=m_{d r} \cdot \frac{\left(X_{w m}-X_{d}\right)}{\left(100-X_{w m}\right)}$

where $m_{d m}$ is amount of withered leaf , $m_{e v}$ amount of evaporate water; $m_{w m}$ amount of wet material; $X_{w m}$ moisture content of fresh tea leaves; $D M_{c}$ dry matter content; $m_{d r}$ amount of dried material; and $X_{d}$ moisture content of withered leaf.

\subsubsection{Potential environmental impacts}


The potential environmental impacts (PEI) associated with the production of tea are evaluated using the CML 2002 methodology [86]. The method, in compliance with ISO 14040 series, divides a life cycle impact assessment study into classification, characterization, normalization, and weighting. According to Moberg et al., [87], classification is an inventory collection process from life cycle to several impact categories, while characterization entails sorting emissions and resources coming from the inventory into different groups or impact categories according to their potential impact on the environment [88], [89]. The environmental impact categories selected in this study were global warming, acidification, eutrophication, photochemical oxidant formation, and human toxicity. The potential environmental impacts are estimated using the following Eq. (20) and (21) [90]:

$$
\begin{gathered}
P E I_{i}=\sum_{x=1}^{Y}\left(E_{x, i} \cdot C F_{x, i}\right) \\
I_{j}=\sum_{i=1}^{Z}\left(\frac{P E I_{i}}{N_{i}} x V_{i, j}\right)
\end{gathered}
$$

where $P E I$ is the potential environmental impact; $E_{x}$ total emissions of a substance $x ; C F_{x}$ characterization factor, $i$ potential impact category; $N_{i}$ normalisation factor; $V_{i, j}$ valuation factor; $\mathrm{j}$ represents different sets of valuation factors; and $I_{j}$ environmental index.

Normalization is the calculation of the magnitude of the category indicator results relative to reference information. The reference information may relate to a given community (for example, in Malawi, Southern Africa or World), person or other system, over a given period of time [91]. Category indicator results are normalized to better understand the relative importance and magnitude of these values for the studied system [92], [93]. Normalization can be determined based on the formula shown as follows [94].

$N_{i}=S_{i} / R_{i}$

where $S, R$ denotes category indicator and reference value, respectively.

Finally, weighting is conducted by multiplying category indicator with weighting factor and summed to get the score [88].

\subsection{Results and Discussions}

\subsection{Materials and energy inputs}

Table 3 shows the main inputs and outputs for the production of 1 kilogram of made tea. Descriptive statistics for input and output calculations of the analysed factories is also given in Table 4. Inputs to produce black tea include green leaf as the main raw material; energy (electricity, diesel, firewood, water, human labour); and auxiliary materials (chemicals, paper sacks, pallets, straps). The outputs are black tea; wastes including dry waste leaf, boiler ash, tea dust and wastewater; and air emissions. The analysis results show that for the production of $1 \mathrm{~kg}$ black tea, a typical Malawian tea factory uses 4.96 $\mathrm{kg}$ green leaf (GL), $0.64 \mathrm{~kW}$ electricity, $3.35 \mathrm{~kg}$ firewood, 9.2 millilitres of diesel, 0.268 hours of human power, $4.24 \mathrm{~kg}$ water. The results range from 4.19 to $6.33 \mathrm{~kg} / \mathrm{kg}$ for green leaf; 0.42 to $1.08 \mathrm{kWh} / \mathrm{kg}$ for electricity; 1.67 to $8.2 \mathrm{~kg} / \mathrm{kg}$ for firewood; 0.14 to $0.51 \mathrm{MJ} / \mathrm{kg}$ for diesel; $0.104-0.695 \mathrm{hr} . / \mathrm{kg}$ for human 
power; 1.92 to $8.32 \mathrm{~kg} / \mathrm{kg}$ for water; and 1.17 to $6.07 \mathrm{~g} / \mathrm{kg}$ for boiler chemicals. Details of material and energy use are discussed in the following sections.

Table 3

Input and output table for tea production of $1 \mathrm{~kg}$ made tea

\begin{tabular}{lcccccccc}
\hline Parameter & F1 & F2 & F3 & F4 & F5 & F6 & F7 & F8 \\
\hline Inputs & & & & & & & & \\
& & & & & & & & \\
Raw material & & & & & & & & \\
$\quad$ Green leaf (kg) & 6.33 & 4.88 & 4.19 & 6.13 & 4.33 & 4.68 & 4.46 & 4.65 \\
& & & & & & & & \\
Auxiliary materials & & & & & & & & \\
$\quad$ Paper sacks & 0.018 & 0.018 & 0.018 & 0.018 & 0.018 & 0.018 & 0.018 & 0.018 \\
$\quad$ Pallets & 0.0009 & 0.0009 & 0.0009 & 0.0009 & 0.0009 & 0.0009 & 0.0009 & 0.0009 \\
& & & & & & & & \\
Energy & & & & & & & & \\
$\quad$ Electricity(kWh) & 0.61 & 1.08 & 0.47 & 0.61 & 0.61 & 0.73 & 0.58 & 0.42 \\
$\quad$ Firewood (kg) & 3.13 & 3.58 & 1.67 & 2.42 & 3.09 & 2.96 & 8.2 & 1.75 \\
$\quad$ Diesel (litres) & 0.0087 & 0.0132 & 0.0082 & 0.009 & 0.0113 & 0.0036 & 0.0064 & 0.0116 \\
$\quad$ Human (hours) & 0.195 & 0.104 & 0.251 & 0.695 & 0.299 & 0.164 & 0.621 & 0.239 \\
Water (kg) & 4.53 & 7.5 & 1.92 & 8.32 & 2.22 & 3.47 & 3.26 & 2.68 \\
Chemicals (g) & 0.96 & 1.17 & 0.53 & 1.12 & 0.23 & 0.56 & 0.88 & 0.62
\end{tabular}

\section{Outputs}

$\begin{array}{lcccccccc}\begin{array}{l}\text { Black tea } \\ \text { Waste }\end{array} & 1.00 & 1.00 & 1.00 & 1.00 & 1.00 & 1.00 & 1.00 & 1.00 \\ \quad & & & & & & & & \\ \quad \begin{array}{l}\text { Dry/waste } \\ \text { leaf (g) }\end{array} & 0.5 & 0.5 & 0.5 & 0.5 & 0.5 & 0.5 & 0.5 & 0.5 \\ \text { Ash (g) } & 1.07 & 1.79 & 0.78 & 1.99 & 0.39 & 0.8 & 1.53 & 0.96 \\ \text { Tea dust (g) } & 1.2 & 1.2 & 1.2 & 4.94 & 4.47 & 1.2 & 1.2 & 1.2 \\ \text { Waste water (1) } & 0.76 & 2.5 & 0.55 & 1.39 & 0.56 & 1.39 & 1.09 & 0.67\end{array}$

Emissions to the air

$\begin{array}{lrrrrrrrr}\mathrm{CO}_{2}(\mathrm{~kg}) & 5.41 & 5.33 & 2.51 & 3.66 & 4.64 & 4.52 & 4.72 & 3.11 \\ \mathrm{CH}_{4}(\mathrm{~g}) & 35.62 & 34.99 & 16.45 & 24.05 & 30.45 & 29.82 & 31.09 & 20.36 \\ \mathrm{~N}_{2} \mathrm{O}(\mathrm{g}) & 70.13 & 69.07 & 32.50 & 47.45 & 60.11 & 58.75 & 61.29 & 40.25 \\ \mathrm{NO}_{\mathrm{X}}(\mathrm{g}) & 27.56 & 27.45 & 13.07 & 18.75 & 23.87 & 22.76 & 23.95 & 16.29 \\ \mathrm{CO}(\mathrm{g}) & 3.54 & 3.48 & 1.64 & 2.39 & 3.03 & 2.97 & 3.09 & 2.02 \\ \mathrm{NMVOC}(\mathrm{g}) & 0.17 & 0.17 & 0.08 & 0.12 & 0.15 & 0.15 & 0.15 & 0.10 \\ \mathrm{SO}_{2}(\mathrm{~g}) & 1.21 & 1.25 & 0.61 & 0.84 & 1.08 & 0.96 & 1.04 & 0.78\end{array}$

Emissions to water 
$\operatorname{COD}(\mathrm{mg} / \mathrm{l}) \quad \mathrm{n} / \mathrm{a}$

$\operatorname{BOD}(\mathrm{mg} / \mathrm{l})$

335

Table 4

Descriptive statistics of Malawian life cycle inventory for $1 \mathrm{~kg}$ of black tea production

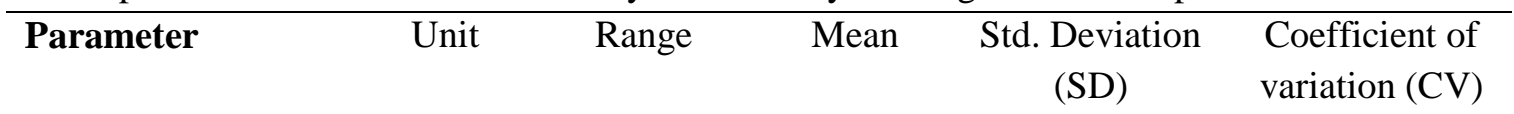

Inputs

Raw Material

Fresh leaf

$\mathrm{kg}$

$4.19-6.33$

4.96

0.816

$16.5 \%$

Energy

$\begin{array}{lccccc}\text { Electricity } & \mathrm{kWh} & 0.42-1.08 & 0.64 & 0.202 & 32 \% \\ \text { Firewood } & \mathrm{kg} & 1.67-8.2 & 3.35 & 2.0733 & 62 \% \\ \text { Diesel } & \mathrm{MJ} & 0.14-0.51 & 0.348 & 0.119 & 34 \% \\ \text { Human power } & \mathrm{hrs} & 0.104-.695 & 0.321 & 0.217 & 68 \% \\ & & & & & \\ \text { ater } & \mathrm{kg} & 1.92-8.32 & 4.24 & 2.414 & 57 \% \\ \text { emicals } & \mathrm{g} & 1.17-6.07 & 0.759 & 0.326 & 43 \%\end{array}$

\section{Output}

Waste

$\begin{array}{lccccc}\text { Dry/waste leaf } & \mathrm{g} & \mathrm{n} / \mathrm{a} & 0.5 & \mathrm{n} / \mathrm{a} & \mathrm{n} / \mathrm{a} \\ \text { Boiler ash } & \mathrm{g} & 0.39-1.99 & 1.164 & 0.553 & 48 \% \\ \text { Dust } & \mathrm{g} & 1.2-4.94 & 2.076 & 1.627 & 78 \% \\ \text { Wastewater } & \mathrm{kg} & 0.55-2.5 & 1.11 & 0.657 & 59 \%\end{array}$

Emissions to air

$\begin{array}{lccccc}\mathrm{CO}_{2} & \mathrm{~kg} & 2.51-5.41 & 4.24 & 1.045 & 25 \% \\ \mathrm{CH}_{4} & \mathrm{~g} & 16.45-35.63 & 27.856 & 6.898 & 25 \% \\ \mathrm{~N}_{2} \mathrm{O} & \mathrm{g} & 32.13-70.13 & 54.94 & 13.562 & 25 \% \\ \mathrm{NOx} & \mathrm{g} & 13.07-27.56 & 21.71 & 5.22 & 25 \% \\ \mathrm{CO} & \mathrm{g} & 1.64-3.54 & 2.77 & 0.687 & 25 \% \\ \mathrm{NMVOC} & \mathrm{g} & 0.08-0.17 & 0.136 & 0.0338 & 25 \% \\ \mathrm{SO}_{2} & \mathrm{~g} & 0.61-1.3 & 0.971 & 0.218 & 25 \%\end{array}$




\subsubsection{Raw material consumption}

Table 1 also presents the results from analysing the amount of green leaf required to manufacture 1 $\mathrm{kg}$ of black tea in the studied factories. The results show that the quantity of green leaf to manufacture $1 \mathrm{~kg}$ of made tea varies from 4.19 to $6.33 \mathrm{~kg}$ green leaf per $\mathrm{kg}$ of made tea. The average specific raw material consumption was calculated to be $4.96 \mathrm{~kg}$ green leaf per $\mathrm{kg}$ of made tea, compared to 4.5 and $4.66 \mathrm{~kg}$ green leaf per $\mathrm{kg}$ of made in Kenya and Sri Lanka, respectively [95]. Compared to fresh leaf consumption values regarded as the best practice of tea industry in the country, reported in [96], the studied factories consume slightly higher green leaf per $\mathrm{kg}$ of made tea. Clearly, this indicates that there is need to improve tea process efficiency of the Malawian tea factories.

\subsubsection{Energy consumption}

Table 5 presents the results from analysing ranges of specific energy consumption among individual tea factories grouped by country based upon available literatures that were reviewed in this study. The average specific electrical and thermal energy consumption across countries varied significantly, ranging from 0.42 to $1.08 \mathrm{kWh} / \mathrm{kg}$ and 5.47 to $14.31 \mathrm{kWh} / \mathrm{kg}$, respectively. The average specific electrical and thermal energy for made tea processed by the Malawian tea industry is found to be $0.64 \mathrm{kWh} / \mathrm{kg}$ and $13.41 \mathrm{KWh} / \mathrm{kg}$ of made tea, respectively. Data found in India exhibited a less yet significant spread (i.e. $0.2-0.5$ and $3.5-6 \mathrm{kWh} / \mathrm{kg}$ made tea, for electrical and thermal energy, respectively. The results of this study indicate that tea processing in Malawi is relatively energy intensive. The highest energy input is provided by fuel (firewood), followed by electricity and human labour. Usage of diesel is comparatively low in all audited factories, as these use generators during power failure periods only. A smaller amount of diesel is also used to power tractors used with the factory. The average wood consumption in Malawian tea factories is $3.35 \mathrm{~kg} / \mathrm{kg}$ made tea compared to 1.38 and $1.372 \mathrm{~kg}$ per $\mathrm{kg}$ made tea in more efficient factories in Sri Lanka and India, respectively [97],[98].These significant differences have indicated large potential energy saving opportunities in the country's tea factories.

Table 5

Comparison of average annual SEC values in selected countries

\begin{tabular}{lcccccc}
\hline Country & \multicolumn{2}{c}{$\begin{array}{c}\text { Specific electrical energy } \\
\text { consumption }(\mathrm{kWh} / \mathrm{kg})\end{array}$} & & \multicolumn{2}{c}{$\begin{array}{c}\text { Specific thermal energy } \\
\text { consumption }(\mathrm{kWh} / \mathrm{kg})\end{array}$} & Source \\
\cline { 2 - 3 } \cline { 5 - 6 } & Average & Range & & Average & Range & \\
\hline Malawi & 0.64 & $0.42-1.08$ & & 13.41 & $5.47-14.31$ & \\
Sri Lanka & 0.46 & $0.69-1.47$ & & 5.26 & $4.45-6.84$ & {$[99],[100]$} \\
Kenya & & $0.44-0.56$ & & 5.33 & $4-23$ & {$[95]$} \\
India & 0.5 & $0.2-0.5$ & & 4.6 & $4.5-6$ & {$[101]$,} \\
& & & & & {$[100]$} \\
Vietnam & & $0.58-0.8$ & & 10 & & {$[100]$} \\
\hline
\end{tabular}

\subsubsection{Water Use}

Results of water usage in the audited factories are summarised in Table 6. The study shows that tea processing requires smaller, but still considerable, amounts of water. Annual water consumption in the analysed factories varies between $4586 \mathrm{~m}^{3}$ and $12120 \mathrm{~m}^{3}$. More than $38 \%$ of the water used in these 
factories is used for boiler-feed water ${ }^{3}$, followed by domestic use ${ }^{4}(34 \%)$ and factory cleaning (26\%). The specific water consumption was found to be low, ranging from 1.92 to $8.32 \mathrm{~kg} / \mathrm{kg}$ made tea with average of $4.24 \mathrm{~kg} / \mathrm{kg}$ made tea and standard deviation of $2.414 \mathrm{~kg} / \mathrm{kg}$ of made tea (see Table 2). This figure is comparable with that of India and Sri Lanka, with specific water consumption of $3.584 \mathrm{~kg} / \mathrm{kg}$ and $8.817 \mathrm{~kg} / \mathrm{kg}$, respectively; and the global average of $7.483 \mathrm{~kg} / \mathrm{kg}$ made tea [102]. The study also established that most factories do not record water flowing in and out of individual processing units as well analyse these waters.

Table 6:

Water usage at selected tea factories

\begin{tabular}{lcccccccc}
\hline \multirow{2}{*}{ Factory } & $\begin{array}{c}\text { Tea } \\
\text { Production }\end{array}$ & \multicolumn{3}{c}{ Water input $\left(\mathrm{m}^{3} \mathrm{~kg}^{-1}\right.$ made tea $)$} & & Wastewater \\
\cline { 3 - 6 } & $\left(\mathrm{kg} \mathrm{yr}^{-1}\right)$ & Total & Boiler & $\begin{array}{c}\text { Factory } \\
\text { cleaning }\end{array}$ & $\begin{array}{c}\text { Domestic } \\
\text { \& others }\end{array}$ & & \\
$\left(\mathrm{m}^{3} \mathrm{~kg}^{-1}\right)$ & $\left(\mathrm{kg} \mathrm{kg}^{-1}\right)$ \\
\hline F1 & $1,311,043$ & 0.00453 & 0.00181 & 0.00076 & 0.00196 & 0.00453 & 4.53 \\
F2 & 1080209 & 0.00750 & 0.00125 & 0.00250 & 0.00375 & 0.00750 & 7.50 \\
F3 & 2384549 & 0.00192 & 0.00109 & 0.00055 & 0.00029 & 0.00192 & 1.92 \\
F4 & 1128068 & 0.00832 & 0.00277 & 0.00139 & 0.00416 & 0.00832 & 8.32 \\
F5 & 5447716 & 0.00222 & 0.00111 & 0.00056 & 0.00056 & 0.00222 & 2.22 \\
F6 & 2252108 & 0.00347 & 0.00069 & 0.00139 & 0.00139 & 0.00347 & 3.47 \\
F7 & 1437728 & 0.00326 & 0.00174 & 0.00109 & 0.00043 & 0.00326 & 3.26 \\
F8 & 2016875 & 0.00268 & 0.00134 & 0.00067 & 0.00067 & 0.00268 & 2.68 \\
\hline
\end{tabular}

\subsubsection{Waste}

Solid waste streams from the analysed factories are composed of dry/waste leaf, dhool spillages, sand and other waste, dust and stalks, tea sweepings, and boiler ash. The analysis indicates that solid waste in these factories account for $0.68 \%$ of total production. The highest amount of waste is produced at withering process $(0.5 \%)$, followed by sorting $(0.1 \%)$, maceration $(0.04 \%)$, fermentation $(0.02 \%)$ and packing $(0.02 \%)$, respectively. Overall, total solid and liquid wastes per $\mathrm{kg}$ of made tea is calculated to be $2.48 \%$ which compares well with a figure of $2 \%$ given in the literature. According to results of this study, the production of 1 kilogram of made tea results in the generation of $0.0235 \mathrm{~kg}$ of dry/waste tea leaves; $1.11 \mathrm{~kg}$ of wastewater; $0.0009 \mathrm{~kg}$ of sweepings; and $0.0002 \mathrm{~kg}$ of packing wastes.

Results further show that a considerable amount of effluent is produced by tea factories. The effluent generated by tea factories originates from the washing of equipment within the factories. The specific wastewater generated range from $0.00055-0.0025 \mathrm{~m}^{3} / \mathrm{kg}(0.55-2.5 \mathrm{~kg} / \mathrm{kg})$, and is about $1.8 \%$ of total tea production. Effluent from tea factory wetlands was found to contain a biological oxygen demand (BOD) of $335 \mathrm{mg} / \mathrm{l}$ compared to a national standard of $20 \mathrm{mg} / \mathrm{l}$. This is an indicator that effluent from tea factories has significant impact on this water quality parameter. There were no data on chemical oxygen demand (COD), total dissolved solids (TDS), and total suspended solids (TSS), making it impossible to draw conclusions based on the available data. Despite having little quantitative evidence about the extent of this on the analysed factories, the study identified waste water generation to be a potentially significant cause of environmental impacts for the Malawian tea industry. Further studies are

\footnotetext{
3 Boiler feed water: water introduced into boilers for conversion to steam

4 Domestic water: water used for drinking, showers, and flushing wastes, etc
} 
required to substantiate this claim. Also, the study also reveals that many tea factories fail to collect data on the environmental implications of their operations.

\subsubsection{Emissions}

Greenhouse gas (GHGs) emissions and other pollutants to produce $1 \mathrm{~kg}$ of tea in the studied factories are provided in Table 2. Tables 7 and 8 show the comparison of GHG and non-CO2 GHG emissions due to fuel combustion by country, based upon available literatures that were reviewed in this study. Results showed that among the three GHGs considered for the estimation the most important contribution is due to carbon dioxide (98\%), followed by nitrous oxide $(1.3 \%)$ and methane $(0.7 \%)$. Total carbon dioxide emissions vary significantly across countries, ranging from 2.51 to $5.41 \mathrm{~kg} \mathrm{CO}$ $/ \mathrm{kg}$ made tea. The average $\mathrm{CO}_{2}$ emission to produce $1 \mathrm{~kg}$ of tea in the sample factories was $4.24 \mathrm{~kg}$, higher than results from other studies [34]. Specific $\mathrm{CO}_{2}$ emissions in India, Sri Lanka and Vietnam were found to be $2.15 ; 2.49$; and $2.86 \mathrm{~kg} \mathrm{CO}_{2} / \mathrm{kg}$, respectively. Nitrous oxide emissions vary from 32.50 $\mathrm{g} \mathrm{N}_{2} \mathrm{O} \mathrm{kg}{ }^{-1}$ to $70.13 \mathrm{~g} \mathrm{~N}_{2} \mathrm{O} / \mathrm{kg}$, with an average of $54.94 \mathrm{~N}_{2} \mathrm{O} / \mathrm{kg}$ of made tea. Average emissions of methane were calculated to be $27.86 \mathrm{~g} \mathrm{CH}_{4} / \mathrm{kg}$ of made tea.

\section{Table 7}

Comparison of GHG emissions due to fuel combustion in selected countries

\begin{tabular}{lccccc}
\hline & \multicolumn{4}{c}{$\mathrm{Kg} / \mathrm{kg}$ made tea } & \multicolumn{2}{c}{ Source } \\
\cline { 2 - 5 } & $\mathrm{CO}_{2}$ & $\mathrm{~N}_{2} \mathrm{O}$ & $\mathrm{CH}_{4}$ & $\mathrm{CO}_{2}-\mathrm{e}$ & \\
\hline Malawi & 4.24 & 0.055 & 0.028 & 4.32 & This study \\
Kenya & & & & 2.27 & {$[95]$} \\
India & 2.15 & & & & {$[100]$} \\
Sri Lanka & 2.49 & & & 2.7 & {$[100],[95]$} \\
Vietnam & 2.86 & & & & {$[100]$} \\
\hline
\end{tabular}

Total GHG equivalent emissions were calculated to be $4.32 \mathrm{~kg}$ of $\mathrm{CO}_{2}$-eq $/ \mathrm{kg}$ of made tea as compared to 2.27 and $2.7 \mathrm{~kg} \mathrm{CO}_{2}$-eq $/ \mathrm{kg}$ in similar factories in Kenya and Sri Lanka, respectively [95]. These results highlight the need to optimize tea production processes in the Malawian tea industry with a view to reduce these emissions. Sulphur dioxide is another pollutant emitted from fuel combustion which is of concern because of its contribution to acid rain. The specific $\mathrm{SO}_{2}$ emission was found to be $0.97 \mathrm{~g} \mathrm{SO}_{2} / \mathrm{kg}$ compared to $0.016 \mathrm{~g} \mathrm{SO}_{2} / \mathrm{kg}$ made tea in India. Specific $\mathrm{CO}$ emissions is also lowest in Malawian tea factories at $2.77 \mathrm{~g} \mathrm{CO} / \mathrm{kg}$ made tea, compared to $25 \mathrm{~g} \mathrm{CO} / \mathrm{kg}$ in Sri Lanka and $5.6 \mathrm{~g} \mathrm{CO} /$ $\mathrm{kg}$ in Vietnam. Average non-methane volatile compounds (NMVOC) and nitrous oxide (NOx) emissions were calculated as $0.14 \mathrm{~g}$ NMVOC $/ \mathrm{kg}$ and $21.71 \mathrm{~g} \mathrm{NOx} / \mathrm{kg}$ of made tea.

\section{Table 8}

Comparison of non- $\mathrm{CO}_{2} \mathrm{GHG}$ due to fuel combustion in selected countries

\begin{tabular}{lccccc}
\hline & \multicolumn{4}{c}{$\mathrm{g} / \mathrm{kg}$ made tea } & \multicolumn{2}{c}{ Source } \\
\cline { 2 - 5 } & $\mathrm{SO}_{2}$ & $\mathrm{CO}$ & $\mathrm{NMVOC}$ & $\mathrm{NOx}$ & \\
\hline Malawi & 0.97 & 2.77 & 0.14 & 21.71 & This study \\
Kenya & & & & & {$[95]$} \\
India & 0.016 & & & & {$[100]$}
\end{tabular}




\subsection{Mass flows in tea processing}

Figure 3 presents the results of material balances in a typical black tea processing factory in Malawi. Green leaf having $20-25 \%$ dry matter and $75-80 \%$ moisture is withered to $68 \%$ moisture and $32 \%$ dry matter. Mass balance results show that with a feed of $4.96 \mathrm{~kg}$ green tea leaves (20\% TS), the following products are obtained: withered leaf $(3.36 \mathrm{~kg})$, dry/waste leaf $(0.0235 \mathrm{~kg})$. The amount of water evaporated in the withering troughs is $1.60 \mathrm{~kg}$. The amount of air required for withering depends on the ambient conditions, and for $4.96 \mathrm{~kg}$ of green tea leaves, approximately $232.5 \mathrm{~kg}$ of air may be needed. The average flow rate of air for the withering process is calculated to be $0.0094 \mathrm{~m}^{3} / \mathrm{s}$. There is no change in the mass flow of tea as well as material loss through the rolling process. However, the study provided for $0.5 \%$ maximum moisture loss on the fermenting machines, calculated as $0.053 \mathrm{~kg}$. The amount of water used for washing is assumed to be $0.006 \mathrm{~kg}$, but is not process-related. Fermented dhool enters the dryer with moisture content of around $68 \%$ and is dehydrated to $97.5 \pm 0.5 \%$ total solids (TS) and $2.5 \pm 0.5 \%$ moisture. Thus from $3.307 \mathrm{~kg}$ fermented dhool, $1.073 \mathrm{~kg}$ (approximately $1 \mathrm{~kg}$ ) of dried tea is produced. The amount of water evaporated during drying is determined to be $2.233 \mathrm{~kg}$, while the amount of air required for drying is found to be $10176 \mathrm{~kg}$.

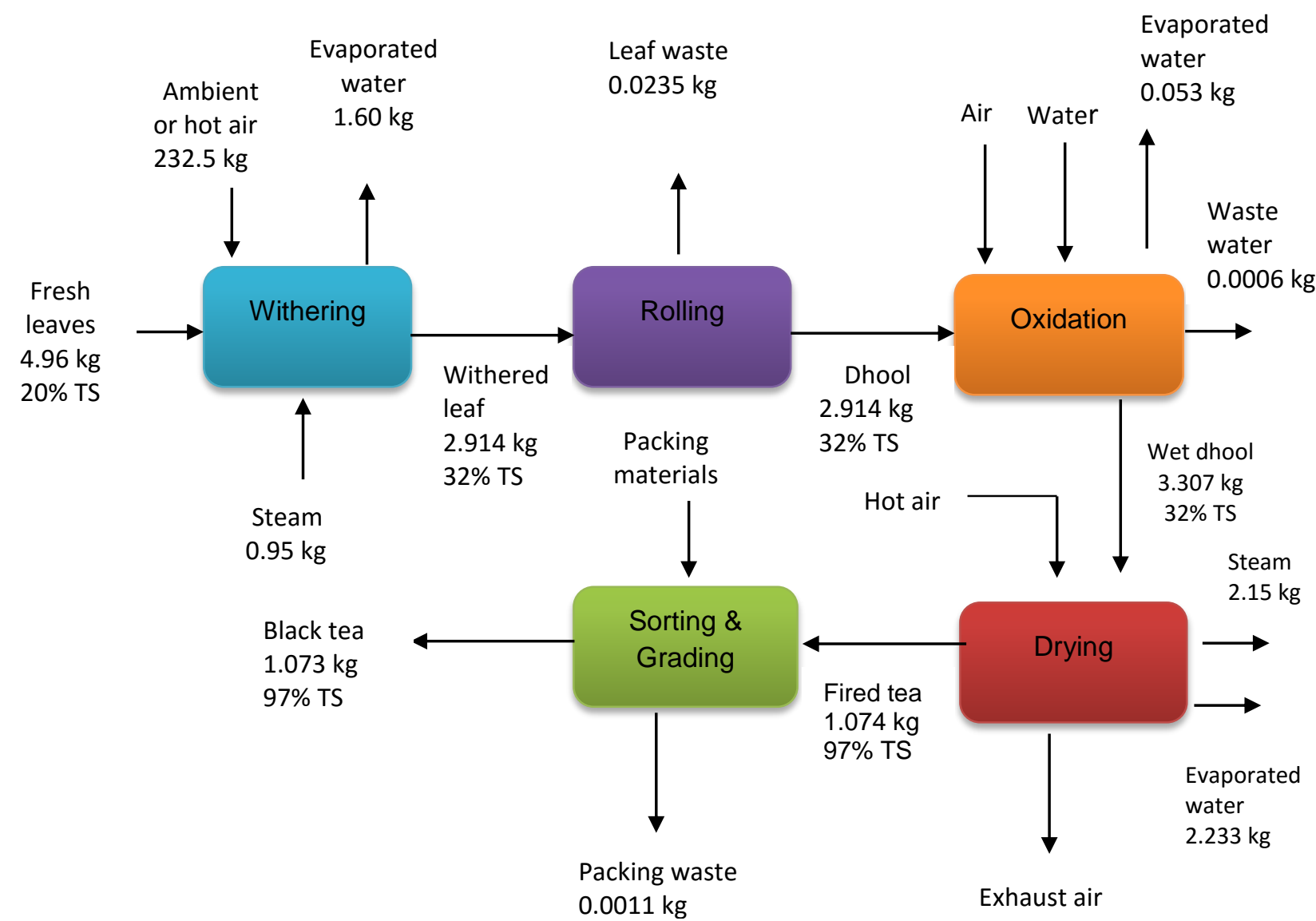

Figure 3: Material balances in black tea processing factory 


\subsection{Energy flows}

Table 9 summarizes and compares the specific energy consumption for unit operations of tea processing across countries. The total energy consumption for tea processing in Malawi is estimated at $8.47 \mathrm{kWh} / \mathrm{kg}$ with thermal $(85 \%)$ and electrical (15\%) of the total energy input. Drying consumes the highest energy with $6.37 \mathrm{kWh} / \mathrm{kg}(78.2 \%)$, followed by withering process with $0.83 \mathrm{kWh} / \mathrm{kg}(16 \%)$, while sorting and grading accounted for the least energy with $0.08 \mathrm{kWh} / \mathrm{kg}(1 \%)$. Furthermore, the study found that energy consumption, particularly withering process varied according to climatic conditions, the quantity and quality of plucked tea leaves, and the spreading conditions of green leaf in the troughs. Energy consumption in withering ranges between. Results obtained in this study shows 0that Indian factories consume less amount of withering while Malawian factories consume the highest energy in withering. Specific energy consumption was calculated as 8.47; 7.25, and 5.11 for Malawi, Sri Lanka, and India, respectively.

Table 9

Comparison of energy consumption for unit operations of tea processing in selected countries

\begin{tabular}{|c|c|c|c|c|c|c|c|}
\hline & \multicolumn{2}{|c|}{ Malawi } & \multicolumn{2}{|c|}{ Sri Lanka } & \multicolumn{2}{|c|}{ India } & \multirow[t]{2}{*}{ Source } \\
\hline & SEEC & STEC & $\begin{array}{r}\text { SEEC } \\
(\mathrm{k}\end{array}$ & $\begin{array}{l}\text { STEC } \\
2 / \mathrm{kg})\end{array}$ & SEEC & STEC & \\
\hline Withering & 0.53 & 0.83 & 0.46 & 2.5 & 0.1 & 0.59 & [100] \\
\hline Rolling/CTC & 0.31 & & 0.20 & & 0.29 & & [100] \\
\hline Fermentation & 0.09 & & & & & & \\
\hline Drying & 0.25 & 6.37 & 0.07 & 3.81 & 0.1 & 3.86 & [100] \\
\hline Sorting & 0.08 & & 0.09 & & 0.16 & & [100] \\
\hline Total & 1.27 & 7.2 & 0.94 & 6.31 & 0.65 & 4.36 & \\
\hline
\end{tabular}

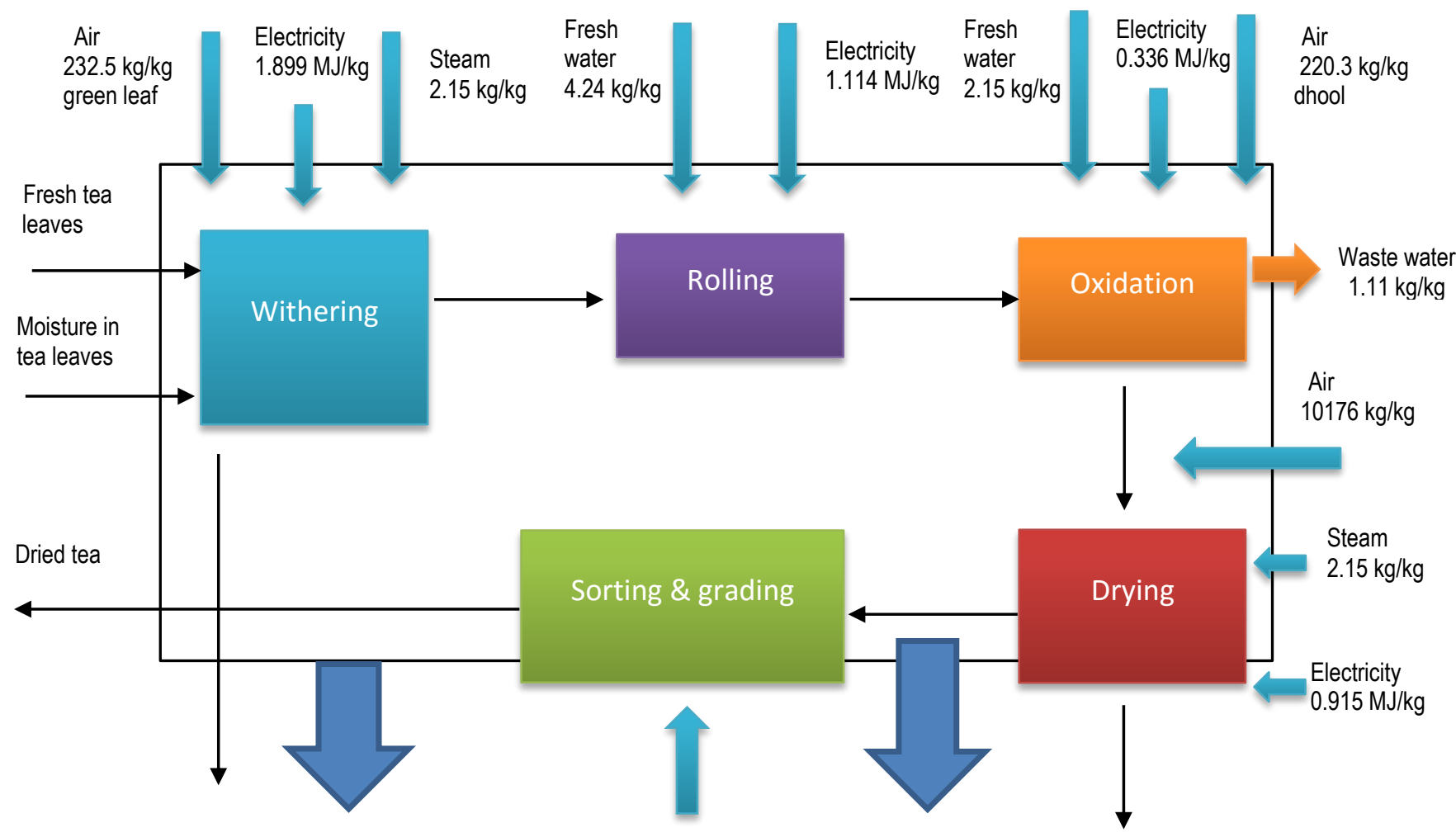




$\begin{array}{ccccc}\text { Evaporated water } & \text { Exhaust air } & \text { Electricity } & \text { Exhaust air } & \text { Evaporated water } \\ 1.60 \mathrm{~kg} / \mathrm{kg} & 232.5 \mathrm{~kg} / \mathrm{kg} & 0.301 \mathrm{MJ} / \mathrm{kg} & 10176 \mathrm{~kg} / \mathrm{kg} & 2.233 \mathrm{~kg} / \mathrm{kg}\end{array}$

Figure 4: Energy flow diagram of tea processing factory

Energy flows in the analysed tea factories are calculated based on energy conservation equations and the results are given in Figures 4 and 5. A psychometric chart is used to determine both the inlet and outlet states of air. Thermal and physical properties of tea were taken from the literature [103]. In this study, the air inlet temperature (before withering) is taken as $26.5^{\circ} \mathrm{C}$ and relative humidity $70 \%$, resulting in a water content of $0.013 \mathrm{~kg}$ water kg${ }^{-1}$ dry air, according to the enthalpy diagram. The energy balances show the withering process will dehydrate $4.96 \mathrm{~kg}$ of green leaf to $3.36 \mathrm{~kg}$ of withered leaf (32\% TS), removing $1.60 \mathrm{~kg}$ of water. The heat energy required for withering $4.96 \mathrm{~kg}$ of tea leaves was determined to be $2900 \mathrm{~kJ}$. The corresponding energy per $\mathrm{kg}$ of water, as $2900 \mathrm{~kJ}$ is required to remove $1 \mathrm{~kg}$ of water was calculated to be $1450 \mathrm{~kJ}$. The amount of air entering the trough is estimated to be $232.5 \mathrm{~kg}$. Firewood used in the withering process for dehydration of water is $0.21 \mathrm{~kg} \mathrm{~kg}^{-1}$ of water removed. The amount of steam used for removal of water is determined to be $0.95 \mathrm{~kg}$ steam per $\mathrm{kg}$ of water evaporated.

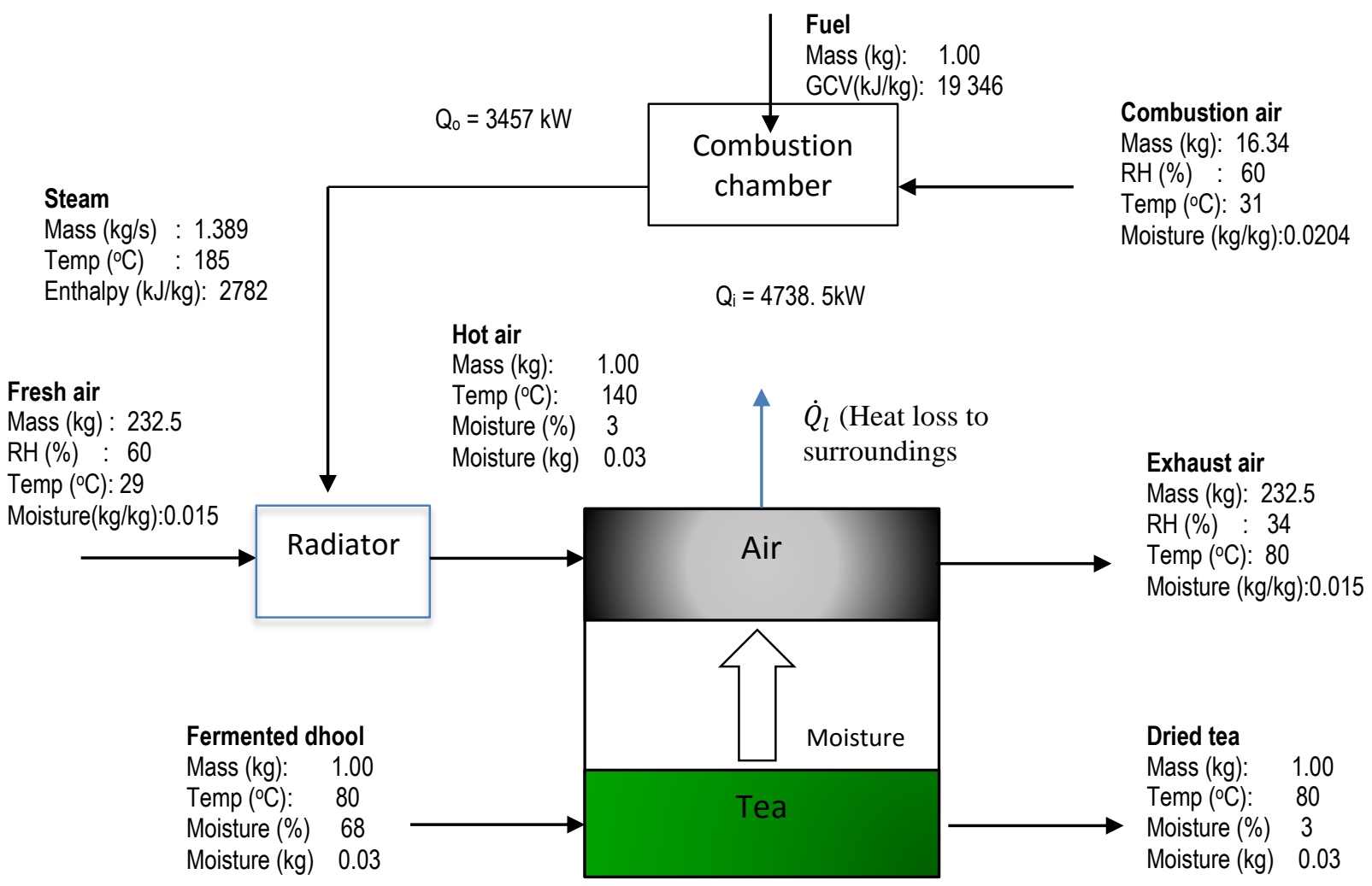

Figure 5: Energy calculations for drying tea leaves

Total air mass flow rate is $32.2 \mathrm{~kg} / \mathrm{s}$ and the product mass flow rate is then calculated to be $0.167 \mathrm{~kg}$ $\mathrm{s}^{-1}$. The fluidized bed dryer will dehydrate $2.233 \mathrm{~kg}$ of fermented dhool to $1.07 \mathrm{~kg}$ of made tea (97\% TS), removing $1.97 \mathrm{~kg}$ of water. The heat energy required for drying $2.233 \mathrm{~kg}$ of fermented dhool was determined to be $3809 \mathrm{~kJ}$. The corresponding energy per $\mathrm{kg}$ of water removed was calculated to be 1450 $\mathrm{kJ}$. The amount of firewood used in fluidized bed drying for removal of water is $0.21 \mathrm{~kg}$ firewood per $\mathrm{kg}$ of water removed. The amount of steam used for removal of water is determined to be $2.15 \mathrm{~kg}$ steam per $\mathrm{kg}$ of water evaporated, while the unit energy input rate to the dryer is calculated to be $3718 \mathrm{~kJ} / \mathrm{h}$. 
The main heat source in the process is firewood and the input heat rate is $6003 \mathrm{~kJ} / \mathrm{h}$. The evaporation rate in the fluidized bed dryer was $0.027 \mathrm{~kg}$ water per $\mathrm{kg}$ leaf per hour.

\subsection{Environmental impacts}

The life cycle impact assessment (LCIA) method used for this study is the CML 2002, which defines an environmental profile by quantifying the environmental effect of various processes analysed [104]. Table 10 presents the potential impacts, normalisation, and normalised potential impact results for the production of $1 \mathrm{~kg}$ of made tea in Malawi. Normalized results for a typical tea processing factory is shown in Figure 6. There are five impact categories for this life cycle impact assessment applied in this study: acidification, eutrophication, global warming, photo-oxidant formation, and human toxicity. The analysis clearly shows that the highest environmental impact is global warming (88\%) followed by acidification (6\%) and eutrophication (2\%), whereas that of human toxicity is lowest. Boiler fuel combustion and diesel for stand-by power generation were the main fuels that contribute to these environmental impacts.

\section{Table 10}

Potential impacts, normalisation and resulting normalised potential impacts for impact categories

\begin{tabular}{lccl}
\hline Impact category & $\begin{array}{l}\text { Potential } \\
\text { impact } \\
\left(P I_{i}\right)\end{array}$ & $\begin{array}{l}\text { Normalisation } \\
\text { factors }\left(N_{\mathrm{i}}\right)\end{array}$ & $\begin{array}{l}\text { Normalised } \\
\text { potential } \\
\text { impact }\left(P I_{i} / N_{i}\right)\end{array}$ \\
\hline Acidification Potential (AP) in $\mathrm{kg} \mathrm{SO}_{2}$-eq. & 0.01205 & $2.34 \mathrm{E}+11$ & $5.01 \mathrm{E}-13$ \\
Eutrophication Potential (EP) in $\mathrm{kgPO}_{4}^{3-}$ eq. & 0.002822 & $1.77 \mathrm{E}+11$ & $5.14 \mathrm{E}-14$ \\
$\begin{array}{l}\text { Global Warming Potential (GWP 100 years) in kg } \\
\mathrm{CO}_{2} \text {-eq. }\end{array}$ & 21.14 & $4.22 \mathrm{E}+13$ & $1.59 \mathrm{E}-14$ \\
$\begin{array}{l}\text { Human toxicity Potential (HTP) in kg DCB-eq. } \\
\text { Photochemical Oxidant Formation Potential }\end{array}$ & 0.026236 & $7.19 \mathrm{E}+11$ & $1.2 \mathrm{E}-14$ \\
(POCP) in $\mathrm{kg} \mathrm{C}_{2} \mathrm{H}_{4}$-eq. & 0.000546 & $4.55 \mathrm{E}+10$ & $3.65 \mathrm{E}-14$ \\
\hline
\end{tabular}

DCB: 1.4-dichlorobenzene

Results of this study also indicate that nitrous oxide and nitrogen oxides are the main contributors, with $16.26 \mathrm{~kg} \mathrm{CO} 2 \mathrm{eq} / \mathrm{kg}$ of and $0.0109 \mathrm{~kg} \mathrm{CO} 2 \mathrm{eq} / \mathrm{kg}$ of made tea, for global warming and acidification, respectively. The total impact associated with global warming and acidification is calculated as 21.14 $\mathrm{kg} \mathrm{CO} 2 \mathrm{eq} / \mathrm{kg}$ and $0.012 \mathrm{~kg} \mathrm{CO} 2 \mathrm{eq} / \mathrm{kg}$ of made tea, respectively. These results provide a first impression of the contribution of the Malawian tea industry towards these five environmental impacts. 


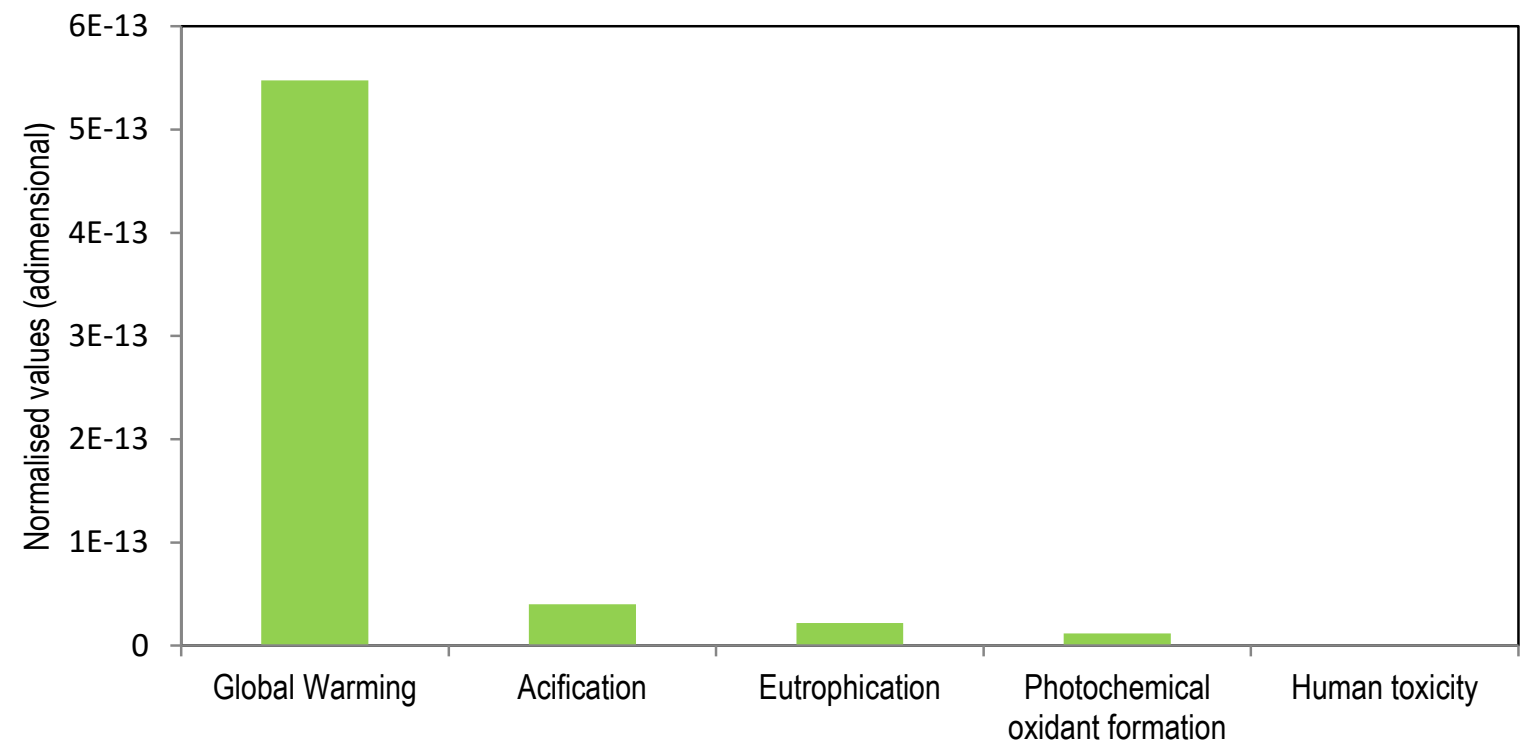

Figure 6: Normalised results for tea production using CML 2000 methodology

\subsection{Conclusions}

This paper has reviewed the relevant literature on material and energy flow analysis, discussed the concept, methodology and its applicability to the tea industry. The review has also presented analysis results of material and energy flows that take part in black tea manufacture in Malawi. The essence of this study is to identify improvement opportunities in the tea manufacturing process and reduce their environmental impacts while maximising economic, social and environmental benefits. The results obtained are of significance to tea factories as they can be used to modify the operating conditions of factories in terms of material usage, amounts of electricity and firewood consumed, water usage, wastewater generation and emissions. The study discussed in the paper leads to the following major findings and conclusions:

The overall energy and material inputs in tea factories in Malawi is higher compared with factories in Kenya, India and Sri Lanka. The study reveals that $4.96 \mathrm{~kg}$ green leaf, $0.64 \mathrm{kWh}$ electricity, $3.55 \mathrm{~kg}$ firewood, $9.2 \mathrm{ml}$ diesel, 0.268 hours of human power, and $4.24 \mathrm{~kg}$ water are used to manufacture $1 \mathrm{~kg}$ of black tea. The specific raw material consumption varies significantly from 4.19 to $6.33 \mathrm{~kg}$ green leaf per $\mathrm{kg}$ of made tea, with an average of $4.69 \mathrm{~kg}$ green leaf per $\mathrm{kg}$ made tea, compared to 4.5 and $4.66 \mathrm{~kg}$ green leaf per $\mathrm{kg}$ of made tea for factories in Kenya and Sri Lanka, respectively. The average wood consumption in these factories is $3.35 \mathrm{~kg}$ of firewood per $\mathrm{kg}$ of made tea compared to 1.38 and $1.372 \mathrm{~kg}$ of wood per kg of made tea in more efficient factories in Sri Lanka and India, respectively; while the specific water consumption varies from 1.92 to $8.32 \mathrm{~kg}$ of water per $\mathrm{kg}$ made tea, with the mean of 4.24 $\mathrm{kg}$ of water per $\mathrm{kg}$ of dried tea, clearly indicating a huge consumption per $\mathrm{kg}$ of made tea.

Energy consumption per $1 \mathrm{~kg}$ of made tea varied significantly in tea factories under study, resulting in similar differences in emissions. Significant amounts of GHG emissions associated with tea processing at factory level were found from the combustion of boiler fuel and diesel for stand-by power generation. The study found that $4.24 \mathrm{~kg} \mathrm{CO}_{2}, 54.94 \mathrm{~g} \mathrm{~N}_{2} \mathrm{O}, 27.86 \mathrm{~g} \mathrm{CH}_{4}, 0.97 \mathrm{~g} \mathrm{SO}_{2}, 2.77 \mathrm{~g} \mathrm{CO}, 0.14 \mathrm{~g}$ NMVOC, and $27.71 \mathrm{~g}$ NOx are emitted to the air per kg of black tea produced. GHG emissions from tea production are estimated to be $4.32 \mathrm{~kg}$ of $\mathrm{CO}_{2}$-eq $/ \mathrm{kg}$ made tea compared to $2.27 \mathrm{~kg} \mathrm{CO}_{2}$-eq $/ \mathrm{kg}$ in similar factories in Kenya. Analysis results show that the highest environmental impact is global warming ( 88 percent) followed by acidification ( 6 percent) and eutrophication (2percent), whereas that of human toxicity is lowest. These results highlight the need to optimize tea production processes with a view to reduce these emissions. 
The results of this study further reveal that withering process requires $2900 \mathrm{~kJ}$ of energy to remove $1.6 \mathrm{~kg}$ water, using $232.5 \mathrm{~kg}$ of air and $0.95 \mathrm{~kg}$ steam. The specific energy use in the withering process is calculated to be $1450 \mathrm{~kJ}$ per $\mathrm{kg}$ made tea. The study also found that drying is by far the most energyconsuming operation within the tea industry. However, the heat energy required per $\mathrm{kg}$ of water evaporated is higher than that energy required in withering troughs. The specific energy use in fluidized bed drying was determined to be $1776.6 \mathrm{~kJ} / \mathrm{kg}$ water evaporated. The amount of firewood and steam used were $0.21 \mathrm{~kg}$ and $2.15 \mathrm{~kg}$, respectively.

The findings demonstrate how MEFA provides early recognition of environmental problems and how it can be used to establish priorities for operating changes over existing factories. These results highlight a very small portion of the life cycle of black tea production since it considered the processing stage only. Further work is required to substantiate the claims made in this study; to initiate continuous resource efficiency analysis in the Malawian tea industry; and to extend the system boundary to include tea cultivation, production and transportation to factory.

\section{Acknowledgements}

The authors gratefully acknowledge financial support of this research by the Department of Mechanical \& Mechatronic Engineering, Stellenbosch University, Eskom TESP program and the National Research Fund (NRF). Furthermore, the authors would like to thank the tea companies for the collaboration in providing first-hand information and data used in this study.

\section{References}

1. UNDP, Malawi National Export Strategy 2013 - 2018. 2012, United Nations Development Programme: Malawi Country Office, Lilongwe, Malawi.

2. FAO, FAOSTAT online database. 2014.

3. FAO, Technical note: Analysis of price incentives for tea in Malawi 2005-2013. 2015: Rome, Italy.

4. TAML, Tea Production Statistics, T.A.o. Malawi, Editor. 2014: Blantyre, Malawi.

5. Clay, J., World agriculture and the environment : a commodity -by-commodity guide to impacts and practices 2004, Washington DC: Island Press.

6. Wal Sanne Van der., Sustainability in the Tea Sector: A comparative analysis of six leading producing countries. 2008, SOMO (Stichting Onderzoek Multinationale Ondernemingen): Amsterdam, Netherlands.

7. Maghanga, J., et al., Electrochemical treatment of a Kenyan tea factory wastewater. J.Agri.pure.app.sci.technol, 2009. 2: p. 68-75.

8. Oirere, S.B., et al., Assessment of waste management structures for tea factories in Kenya: A case study of Nyansiongo tea factory. . 2014, University of Nairobi: Nairobi, Kenya.

9. Brunner, P.H. and H. Rechberger, Practical Handbook of Material Flow Analysis. 2004, Boca Raton: Lewis Publishers.

10. Baccini, P. and P.H. Brunner, Metabolism of the anthroposphere. 1991, New York: Springer.

11. Ayres, R.U. and L.W. Ayres, Industrial ecology: towards closing the materials cycle. 1996, Brookfield: Edward Elgar.

12. $\mathrm{Hu}, \mathrm{C}$., et al., Sulfur Flow Analysis for New Generation Steel Manufacturing Process. International Journal of Iron and Steel Research 2008. 15(4): p. 12-15.

13. Binder, C.R., From material flow analysis to material flow management. Part I; Social sciences modelling approaches coupled to material flow analysis. Journal of Cleaner Production, 2007. 15: p. 1596-1604.

14. Sendra, C., X. Gabarrel, and T. Vicent, Material flow analysis adapted to an industrial area. Journal of Cleaner Production, 2007. 15: p. 1706-1715. 
15. Torres Rodriguez, M.T., et al., Combining LCT tools for the optimization of an industrial process: Material and energy flow analysis and best available techniques. Journal of Hazardous Materials, 2011. 192: p. 1705-1719.

16. Bello Bugallo, P.M., et al., Material flow analysis in a cooked mussel processing industry. Journal of Food Engineering, 2012. 113: p. 100-117.

17. Hashimoto, S. and Y. Moriguchi, Data Book: Material and Carbon Flow of Harvested Wood in Japan. 2004, Center for Global Environmental Research. National Institute for Environmental Studies: Tsukuba.

18. Fischer-Kowalski, M., Society's metabolism. The intellectual history of materials flow analysis, Part 1, 1860-1970. Journal of Industrial Ecology, 1998. 1(1): p. 61-78.

19. Ayres, R.U. and V. Kneese, Production, Consumption and Externalities. American Economic Review, 1969. 59(3): p. 282-297.

20. OECD, Measuring material flows and resource productivity. Volume 1: the OECD Guide. 2008, Paris, France: OECD.

21. Eurostat, Economy - wide Material Flow Accounts and Derived Indicators. A methodological guide. 2001, Luxembourg: Eurostat, European Commission, Office for Official Publications of the European Communities.

22. Graedel, T.E., The contemporary European copper cycle: introduction. Ecological Economics, 2002. 42: p. 5-7.

23. Graedel, T.E., et al., The contemporary European copper cycle: The characterization of technological copper cycles. Ecological Economics, 2002. 42: p. 9-26.

24. Ayres, R.U., The life Cycle of Chlorine: Part 1; Chlorine Production and the Chlorine Mercury Connection. Journal of Industrial Ecology, 1997. 1: p. 81-94.

25. Ayres, R.U., The Life Cycle or Chlorine: Part 2; Conversion Process and Use in the European Chemical Industry. Journal of Industrial Ecology, 1997. 1: p. 65-89.

26. Bringezu, S., et al. Regional and national Material Flow Accounting: From paradigm to practice of sustainability. in Proceedings of the ConAccount workshop. 1997. Leiden, The Netherlands.

27. Ayres, R.U. and U.E. Simonis, (Eds.), ndustrial Metabolism: Restructuring for Sustainable Development. 1994, Tokyo: United Nations University Press.

28. Ayres, R.U., Industrial Metabolism. Technology and Environment, ed. In: J. Ausubel. and H.S. (Eds.):. 1989, Washington D.C.

29. Udo de Haes, H., E.v.d. Voet, and R. Kleijn, From quality to quantity: substance flow analysis (SFA), an analytical tool for integrated chain management. Regional and national material flow accounting: from paradigm to practice of sustainability. , ed. S. Bringezu, Fischer - Kowalski, M., Kleijn, R., Palm, V. editors. 1997, Leiden, the Netherlands: The ConAccount Workshop.

30. Ciacci, L., et al., Historical evolution of anthropogenic aluminium stocks and flows in Italy. Resources, Conservation and Recycling, 2013. 72: p. 1-8.

31. Eckelman, M.J. and I. Daigo, Markov chain modeling of the global technological lifetime of copper. Ecological Economics, 2008. 67(2): p. 265-273.

32. Liu, G. and D.B. Muller, Mapping the global journey of anthropogenic aluminium: a tradelinked multilevel material flow analysis. Environ. Sci. Technol, 2013. 47(20): p. 11873-11881.

33. Dahlstrom, K. and P. Ekins, Combining economic and environmental dimensions: value chain analysis of UK iron and steel flows. Ecological Economics, 2006. 58(3): p. 507-519.

34. Bonnin, M., et al., Development of a dynamic material flow analysis model for french copper cycle. Computers and Chemical Engineering, 2012. 30: p. 122-126.

35. Billen, G., et al., The food-print of Paris: long-term reconstruction of the nitrogen flows imported into the city from its rural hinterland. Reg. Environ. Chang, 2009. 9(1): p. 13-24.

36. Graedel, T.E. and J. Cao. Metal spectra as indicators of development. in Proceedings of the National Academy of Science of the United States of America. 2010.

37. Brunner, P.H., Substance Flow Analysis. A key tool for effective resource management. Journal of Industrial Ecology, 2012.

38. Kuczenski, B. and R. Geyer, Material flow analysis of polyethylene terephthalate in the US, 1996-2007. Resources, Conservation and Recycling, 2010. 54: p. 1161-1169.

39. Chen, W.Q. and T.E. Graedel, Anthropogenic cycles of the elements: A critical review. Environmental Science \& Technology 2012. 46(16): p. 8574-8586. 
40. Smith, R.A., P.I.J. Griffiths, and J. Kersey, Resource flow analysis: measuring sustainability in construction. Proc. ICE - Eng. Sustain, 2003. 156(3): p. 147-155.

41. Hubacek, K. and S. Giljum, Applying physical input-output analysis to estimate land appropriation (ecological footprints) of international trade activities. Ecological Economics, 2003. 44(1): p. 137-151.

42. Müller, D.B., et al. Exploring the engine of anthropogenic iron cycles. in Proceedings of the National Academy of Sciences of the United States of America. 2006.

43. Nakajima, K., et al., Substance flow analysis of molybdenum associated with iron and steel flow in Japanese economy. Isij International, 2007. 47(3): p. 510-515.

44. Daigo, I., et al., Material stocks and flows accounting for copper and copper - based alloys in Japan. Resources, Conservation and Recycling, 2009. 53(4): p. 208-217.

45. Gerst, M.D., Linking Material Flow Analysis and Resource Policy via Future Scenarios of InUse Stock: An Example of Copper. Environmental Science \& Technology 2009. 43(16): p. 6320-6325.

46. Elshkaki, A., et al., Dynamic stock modelling: A method for the identification and estimation of future waste streams and emissions based on past production and product stock characteristics. Energy, 2005. 30(8): p. 1353-1363.

47. Voet, E.v.d., et al., Predicting future emissions based on characteristics of stocks, in Conference on European Environmental History and Ecological Economics, 1999. 2002: Vienna, Austria.

48. Zhang, H., et al., Investigation of the residual heat recovery and carbon emission mitigation potential in a Chinese steelmaking plant: A hybrid material/energy flow analysis case study. Sustainable Energy Technologies and Assessments, 2013. 2: p. 67-80.

49. Habel, H., et al., Progress towards sustainability? What the conceptual framework of material and energy flow accounting (MEFA) can offer Land use Policy, 2004. 21: p. 1999-2013.

50. Suh, S., Theory of materials and energy flow analysis in ecology and economics. Ecological Modeling, 2005. 189: p. 251-269.

51. Billen, G., et al., L'ecosysteme Belgique: essai d'ecologie industrielle., C.d.r.e.d.i. sociopolitigues, Editor. 1983.

52. Thißen, N., Mass and energy flow analysis supports process improvement. Chemical Engineering Technology, 2010. 33(4): p. 573-581.

53. Binder, C.R., et al., Transition towards improved regional wood flows by integrating material flux analysis and agent analysis: the case of appenzell ausserhoden, Switzerland. Ecological Economics, 2004. 49(1): p. 1-17.

54. Cheng, S., et al., Spatial and temporal flows of China's forest resources: development of a framework for evaluating resource efficiency. Ecological Economics, 2010. 69(7): p. 14051415.

55. Liu, J., Forest sustainability in China and implications for a telecoupled world. Asia Pac. Policy Stud, 2014. 1(1): p. 230-250.

56. Wirsenius, S., The biomass metabolism of the food system: model -based survey of the global and regional turnover of food biomass. J. Ind. Ecol., 2003. 7(1): p. 47-80.

57. Narayanaswamy, V., et al., Resource flow and product chain analysis as practical tools to promote cleaner production initiatives. Journal of Cleaner Production, 2003. 11(4): p. 375-387.

58. Mintcheva, V., Indicators for environmental policy integration in the food supply chain (the case of the tomato ketchup supply chain and the integrated product policy. Journal of Cleaner Production, 2005. 13(7): p. 717-731.

59. Virtanen, Y., et al., Carbon footprint of food - approaches from national input-output statistics and a LCA of a food portion. Journal of Cleaner Production, 2011. 19(16): p. 1849-1856.

60. Kytzia, S., M. Faist, and P. Baccini, Economically extended - MFA: a material flow approach for a better understanding of food production chain. Journal of Cleaner Production, 2004. 12: p. 877-889.

61. Rotter, V.S., et al., Material flow analysis of RDF-production processes. Waste Management, 2004. 24: p. 1005-1021.

62. Chancerel, P. and S. Rotter, Recycling - oriented characterization of small waste electrical and electronic equipment. Waste Management, 2009. 29(8): p. 2336-2352.

63. Oguchi.M., et al., Fate of metals contained in waste electrical and electronic equipment in a municipal waste treatment process. Waste Management, 2012. 32(1): p. 96-103. 
64. Bergsdal, H., R.A. Bohne, and H. Brattebo, Projection of construction and demolition waste in Norway. Journal of Industrial Ecology, 2007. 11(3): p. 27-39.

65. Hashimoto, S., H. Tanikawa, and Y. Moriguchi, Where will large amounts of materials accumulated within the economy go? - A material flow analysis of construction materials for Japan. Waste Management, 2007. 27(12): p. 1725-1738.

66. Kleijn, R., R. Huele, and E.v.d. Voet, Dynamic substance flow analysis : the delaying mechanism of stocks, with the case of PVC in Sweden. Ecological Economics, 2000. 32(2): p. 241-254.

67. Herva, M., A. Alvarez, and E. Roca, Combined application of energy and material flow analysis and ecological footprint for the environmental evaluation of a tailoring factory. Journal of Hazardous Materials, 2012. 237: p. 231-239.

68. Muller, E., et al., Material and energy flows and environmental impacts of the internet in Switzerland. Journal of Industrial Ecology, 2013. 17(6): p. 814-826.

69. Torres, M.T., et al., Energy and material flow analysis: Application to the storage stage of clay in the roof-tile manufacture. Energy, 2008. 33: p. 963-973.

70. Baccini, P. and H.P. Bader, Regionaler Stoffhaushalt: Erfssung, Bewertung und Steuerung. 1996, Berlin Heidelberg: Springer Verlag.

71. Hendricks, C., et al., Material flow analysis: a tool to support environmental policy decision making - Case-studies on the City of Vienna and Swiss lowlands. Local Environment, 2000. 5(3): p. 311-328.

72. Ullah, M.R., A.K. Bordoloi, and N. Gogoi, Hastening of leaf senescence in the process of greenleaf to black tea. J.Sci Food Agric, 1986. 37(1042-1044).

73. Roberts, E.A.H. and D.J. Wood, The amino acids and amides of fresh and withered leaf. Curr. Sci, 1951. 20: p. 1-3.

74. Sanderson, G.W., The theory of withering in tea manufacture. Tea Quart, 1964. 35: p. 146-163.

75. Owuor, P.O. and J.E. Orchard, Changes in biochemical constituents of greenleaf and black tea to withering: a Review. Tea 1989. 10: p. 53-59.

76. Ullah, M.R. and P.C. Roy, Effect of withering on the polyphenol oxidase level in the tea leaf. J.Sci Food Agric, 1982. 33: p. 492-495.

77. Wickremasinghe, R.L., Tea. Advances in Food Research, 1975. 24: p. 229-286.

78. Mahanta, P.K. and S. Baruah, Relationship between process of withering and aroma characteristics of black tea. J Sci Food Agric, 1989. 46: p. 461-468.

79. Sanderson, G.W., Change in cell membrane permeability in tea flush on storage after plucking and its effect on fermentation in tea manufacture. J Sci Food Agric, 1968. 19: p. 637-639.

80. Tomlins, K.I. and A. Mashingaidze, Influence of withering, including leaf handling, on the manufacturing and quality of black tea - a review. Food Chemistry, 1997. 60: p. 573-580.

81. Keegel, E.L., Tea manufacture in Ceylon, monographs on tea production in Ceylon. 1983, Tea Research Institute: Ceylon, Sri Lanka.

82. Kothari, C.R., Research Methodology: Methods and Techniques. 2nd ed. 2005, New Delhi: New Age International.

83. Cengel, Y.A. and M.A. Boles, Thermodynamics: an engineering approach. 5th ed. 2006, New York: McGraw-Hill.

84. Dincer, I. and A.Z. Sahin, A new model for thermodynamic analysis of a drying process. International Journal of Heat and Mass Transfer, 2004. 47: p. 645-652.

85. Bhuyan, M., Measurement and control in food processing. 2007, Suite 300 Boca Raton: CRC Press, Taylor \& Francis Group.

86. Guinee, J., et al., Handbook on life cycle assessment: operational guide to the ISO standards. 2002, Dordrecht:: Kluwer Academic Publishers.

87. Moberg, A., et al., Life cycle assessment of energy from solid-waste - part 2: landfilling compared to other treatment methods. Journal of Cleaner Production, 2005. 13: p. 231-240.

88. Bovea, M.D. and A. Gallardo, The influence of impact assessment methods on materials selection for eco-design. Mat. Design, 2006. 27: p. 209-215.

89. Ntiamoah, A. and G. Afrane, Environmental impacts of cocoa production and processing in Ghana: life cycle assessment approach. Journal of Cleaner Production, 2008. 16: p. 1735-1740.

90. Hermann, B.G., C. Kroeze, and W. Jawjit, Assessing environmental performance by combining life cycle assessment, multi-criteria analysis and environmental performance indicators. Journal of Cleaner Production, 2007. 15: p. 1787-1796. 
91. Mangena, S.J. and A. Brent, Application of Life Cycle Impact Assessment framework to evaluate and compare environmental performances with economic values of supplied coal products. Journal of Cleaner Production, 2006. 14: p. 1071-1084.

92. Goedkoop, M., A.N. Schryver, and M. Oele, Introduction to LCA with Simapro 7. 2007, Amersfoort:: PRe Consultants.

93. Eliceche, A., S. Corvalan, and P. Martinez, Environmental life cycle impact as a tool for process optimization of a utility plant. Computers and Chemical Engineering, 2007. 31: p. 648-658.

94. Pennington, D.W., et al., Life cycle assessment part 2: current impact assessment practice. Environ. Int.,, 2004. 30: p. 721-739.

95. Azapagic, A., Life cycle assessment of tea produced in Kenya, Climate change the sector in Kenya: Impact Assessment and Policy Action National Multi-stakeholder Workshop. 2013: Naivasha, Kenya.

96. TRFCA, Tea Planter's Handbook. 1990, Mulanje, Malawi: Tea Research Foundation (Central Africa).

97. UNDP, Energy conservation in small sector tea processing units in South India - Terminal Evaluation Review Report. 2013, United Nations Development Programme: India.

98. Jayah, T.H., Evaluation of a downdraft wood gasifier for tea manufacturing in Sri Lanka. 2002, University of Melbourne: Australia.

99. De Silva, W.C.A., Status review of energy utilization by the tea industry in Sri Lanka. Sri Lanka Journal of Tea Science, 1994. 63(Part 2): p. 46-58.

100. AIT, Small and medium scale industries in Asia: Energy and environment -tea sector. 2002, Asian Institute of Technology: Thailand.

101. Mwenda, I.J., K.J. Ngugi, and K. Jeremiah, Energy consumption trends in smallholder tea factories in Kenya. International Journal of Emerging Technology \& Research, 2015. 2(2): p. $30-43$.

102. Hoekstra, A.Y. and A.K. Chapagain, The waterfoot print of coffee and tea consumption in Netherlands. Ecological Economics, 2007. 64: p. 109-118.

103. Temple, S.J. and A.J.B. van Boxtel, Modelling of fluidized bed-drying of black tea. Journal of Agricultural Engineering Research, 1999. 74(2): p. 203-212.

104. Huijbregts, M.A.J., et al., Normalisation Figures for Environmental Life-Cycle Assessment: The Netherlands (1997/1998), Western Europe (1995) and the World (1990 and 1995). Journal of Cleaner Production, 2003. 11(7): p. 737-748. 